\title{
Variations in amount and direction of seafloor spreading along the northeast Atlantic Ocean and resulting deformation of the continental margin of northwest Europe
}

\author{
E. Le Breton, ${ }^{1,2}$ P. R. Cobbold, ${ }^{1}$ O. Dauteuil, ${ }^{1}$ and G. Lewis ${ }^{3}$ \\ Received 22 December 2011; revised 16 August 2012; accepted 31 August 2012; published 16 October 2012.
}

[1] The NE Atlantic Ocean opened progressively between Greenland and NW Europe

during the Cenozoic. Seafloor spreading occurred along three ridge systems: the Reykjanes Ridge south of Iceland, the Mohns Ridge north of the Jan Mayen Fracture Zone (JMFZ), and the Aegir and Kolbeinsey Ridges between Iceland and the JMFZ. At the same time, compressional structures developed along the continental margin of NW Europe.

We investigate how these compressional structures may have resulted from variations in the amount and direction of seafloor spreading along the ridge system. Assuming that Greenland is rigid and stationary, we have used a least squares method of palinspastic restoration to calculate differences in direction and rate of spreading along the Reykjanes, Kolbeinsey/Aegir and Mohns Ridges. The restoration generates relative rotations and displacements between the oceanic segments and predicts two main periods of left-lateral strike slip along the main oceanic fracture zones: (1) early Eocene to late Oligocene, along the Faeroe Fracture Zone and (2) late Eocene to early Oligocene and during the Miocene, along the JMFZ. Such left-lateral motion and relative rotation between the oceanic segments are compatible with the development of inversion structures on the Faeroe-Rockall Plateau and Norwegian Margin at those times and probably with the initiation of the Fugløy Ridge in the Faeroe-Shetland Basin during the Eocene and Oligocene. The Iceland Mantle Plume appears to have been in a position to generate differential seafloor spreading along the NE Atlantic and resulting deformation of the European margin.

Citation: Le Breton, E., P. R. Cobbold, O. Dauteuil, and G. Lewis (2012), Variations in amount and direction of seafloor spreading along the northeast Atlantic Ocean and resulting deformation of the continental margin of northwest Europe, Tectonics, 31, TC5006, doi:10.1029/2011TC003087.

\section{Introduction}

[2] For the NE Atlantic Ocean (as for most other oceans), there is a consensus that relief at the seafloor results mainly from seafloor spreading. However, volcanic activity has also contributed strongly, especially on and around Iceland and Jan Mayen (Figure 1). The ridge system in the NE Atlantic is complex, and it is convenient to consider it in three parts. From SW to NE, these are the Reykjanes, Jan Mayen and Mohns Segments. Whereas each of the Reykjanes and Mohns Segments has a single ridge, the Jan Mayen Segment has two (the Kolbeinsey and Aegir Ridges). Separating the three segments are systems of transform faults: the Jan Mayen

\footnotetext{
${ }^{1}$ Geosciences Rennes, Université de Rennes 1, CNRS, Rennes, France. ${ }^{2}$ Now at Department of Earth Sciences, Freie Universität Berlin, Berlin, Germany.

${ }^{3}$ Chevron Onshore Europe, Aberdeen, UK.

Corresponding author: E. Le Breton, Department of Earth Sciences, Freie Universität Berlin, Malterserstr. 74-100, 12249 Berlin, Germany. (eline.lebreton@fu-berlin.de)

C2012. American Geophysical Union. All Rights Reserved. 0278-7407/12/2011TC003087
}

Fracture Zone (JMFZ) in the north and the Greenland-IcelandFaroe Fault Zone in the south. The latter is responsible for a notable topographic feature, the Greenland-Iceland-Faeroe Ridge (GIFR).

[3] Seafloor spreading and opening of the NE Atlantic Ocean occurred during the Tertiary period and resulted in a characteristic pattern of magnetic anomalies (Figure 2). Definition of the anomalies is good over most of the sea bottom, except for a swath along the GIFR and south of the JMFZ (Figure 2). Ocean drilling and geophysical investigations have revealed a small continental plate, the Jan Mayen Microcontinent (JMMC; Figure 1), which rifted off Greenland during the Eocene [Bott, 1985, 1987; Gaina et al., 2009; Kodaira et al., 1998; Nunns, 1983; Unternehr, 1982]. The significant bathymetric-topographic highs around Iceland and along the GIFR developed as a result of intense magmatic activity, when the NE Atlantic Ridge interacted with a major thermal and compositional anomaly, the Iceland Mantle Plume [e.g., Saunders et al., 1997]. The magmatic activity modified the magnetic signature of the crust over these areas (Figure 2).

[4] Assuming that Greenland and Eurasia were rigid plates and using Euler rotation poles, Bullard et al. [1965] 


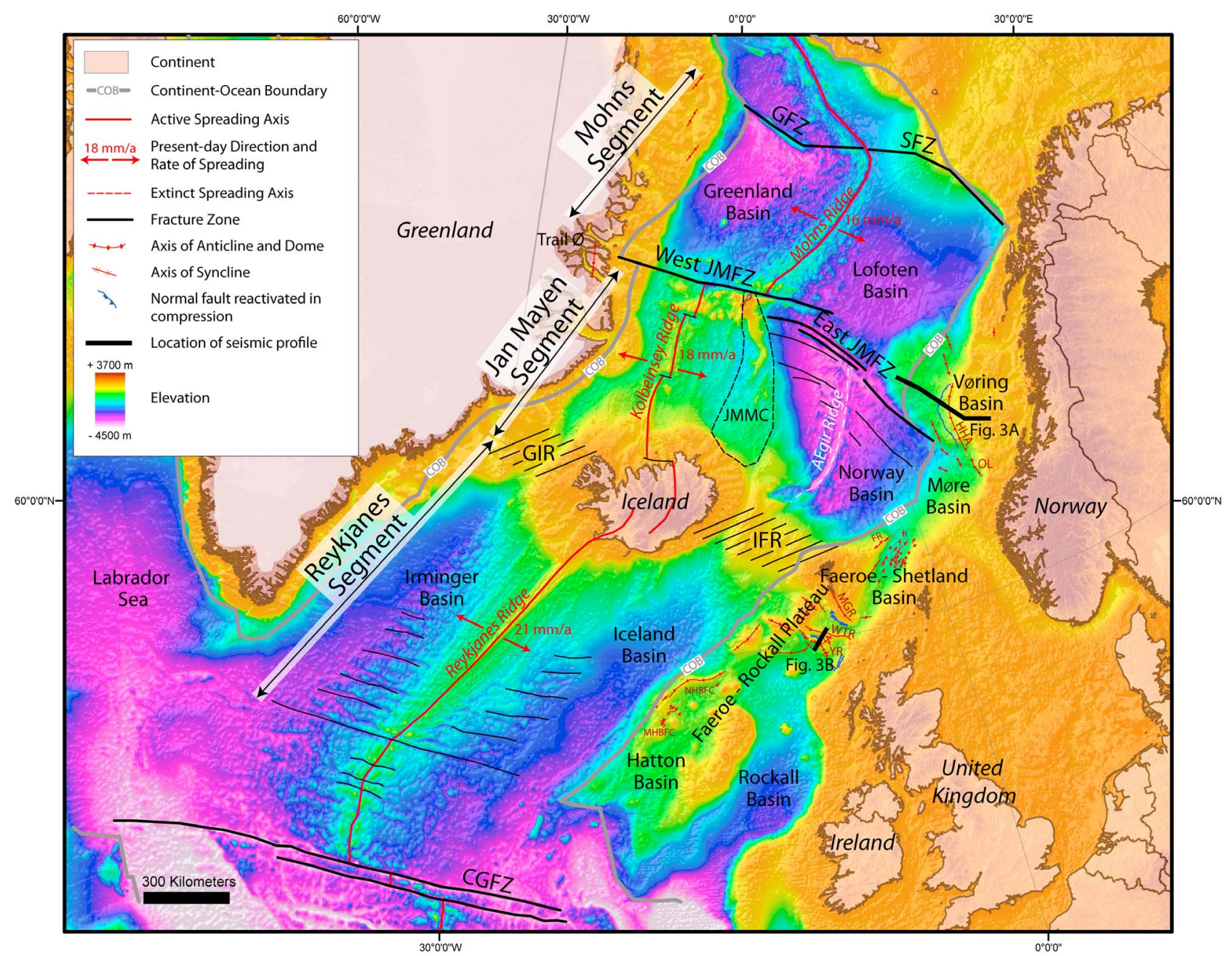

Figure 1. Principal tectonic features of the NE Atlantic Ocean on a bathymetric and topographic map (ETOPO1). Compressional structures (folds and reverse faults) on the NE Atlantic Continental Margin are from Doré et al. [2008], Johnson et al. [2005], Hamann et al. [2005], Price et al. [1997] and Tuitt et al. [2010]. Present-day spreading rates along Reykjavik, Kolbeinsey and Mohns Ridges are from Mosar et al. [2002]. Continent-ocean boundaries of Europe and Greenland are from Gaina et al. [2009] and Olesen et al. [2007]. Black thick lines indicate seismic profiles of Figure 3. Abbreviations (north to south): GFZ, Greenland Fracture Zone; SFZ, Senja Fracture Zone; JMFZ, Jan Mayen Fracture Zone (west and east); JMMC, Jan Mayen Microcontinent; HHA, Helland Hansen Arch; OL, Ormen Lange Dome; FR, Fugløy Ridge; GIR, Greenland-Iceland Ridge; IFR: Iceland-Faeroe Ridge; MGR, Munkagrunnar Ridge; WTR, Wyville Thomson Ridge; YR, Ymir Ridge; NHBFC, North Hatton Bank Fold Complex; MHBFC, Mid-Hatton Bank Fold Complex; CGFZ, Charlie Gibbs Fracture Zone. Map projection is Universal Transverse Mercator (UTM, WGS 1984, zone 27N).

reconstructed the opening of the North Atlantic. However, this led to some gaps and overlaps between the plates. By dividing the ridge system into segments and increasing the number of plates, Gaina et al. [2009] were able to improve the quality of the fit. Nevertheless, it remains difficult to reconstruct a simple spreading history for the complex Jan Mayen Segment, using Euler rotation poles alone, because of the two spreading centers, the JMMC and the significant curvature of the magnetic pattern around the Aegir Ridge (Figure 2).

[5] The continental margins of NW Europe and east Greenland, which consist of stretched continental crust and coeval magmatic rocks, qualify as "volcanic passive margins" [Geoffroy, 2005]. Several sedimentary basins formed on the European margin as a result of rifting: the Vøring and Møre basins in the north, the Faeroe-Shetland Basin in the center and the Hatton and Rockall basins in the south (Figure 1). The area between the Hatton/Rockall and Faeroe-Shetland basins we shall refer to as the FaeroeRockall Plateau. This plateau, as well as the Vøring Basin, contains various compressional structures (folds and reverse faults), which formed after continental breakup [Boldreel and Andersen, 1993; Brekke, 2000; Davies et al., 2004; Doré et al., 2008; Doré and Lundin, 1996; Hitchen, 2004; Johnson et al., 2005; Lundin and Doré, 2002; Løseth and Henriksen, 2005; Ritchie et al., 2003, 2008; Smallwood, 


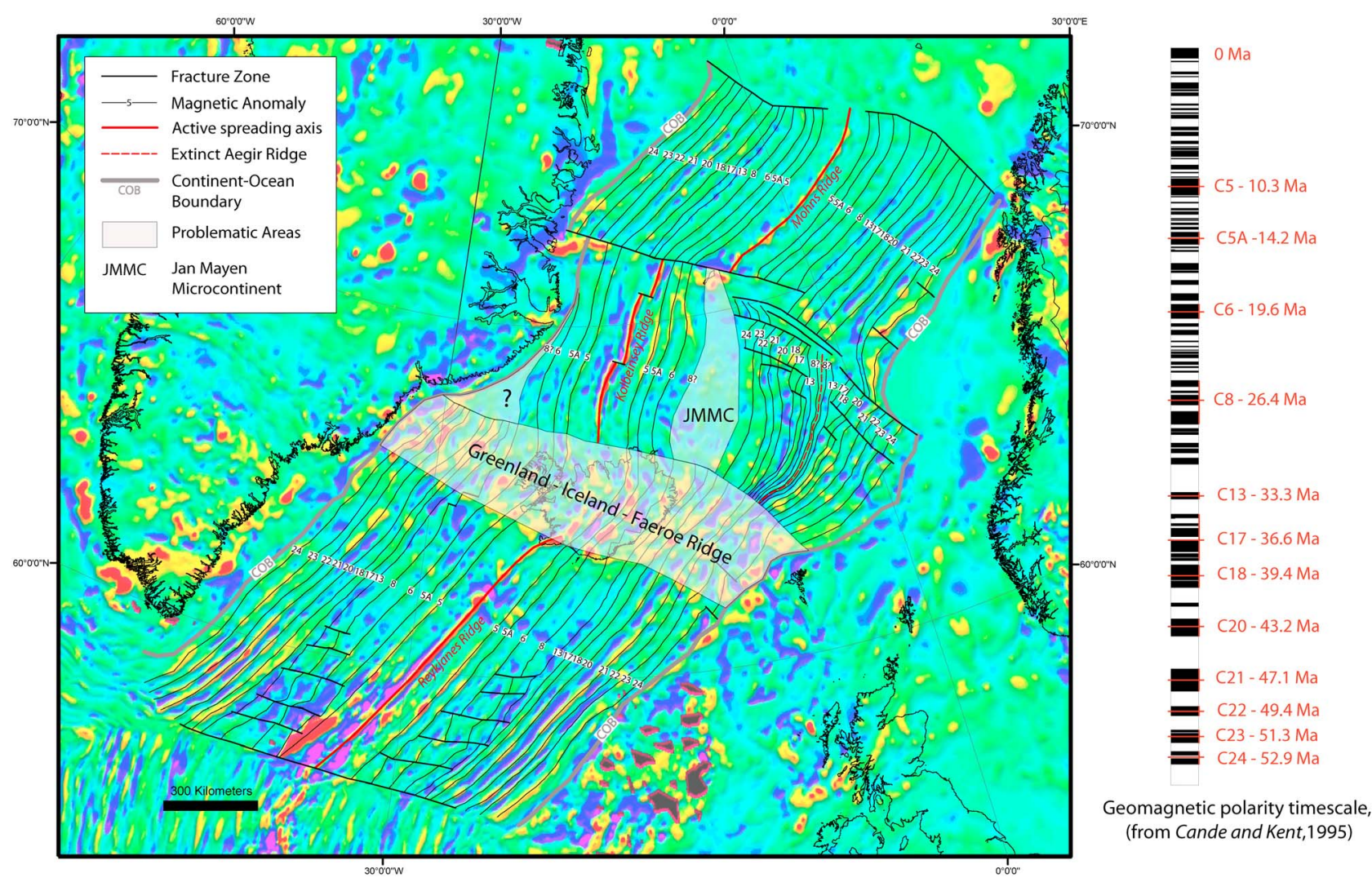

Figure 2. Map of magnetic anomalies, NE Atlantic Ocean. Background image is recent model EMAG2 of crustal magnetic anomalies [Maus et al., 2009]. Ages of magnetic anomalies are from Cande and Kent [1995]. Map projection is Universal Transverse Mercator (UTM, WGS 1984, zone 27N).

2004; Stoker et al., 2005; Tuitt et al., 2010]. In contrast, along the Greenland margin, there is no evidence for postbreakup compressional deformation, other than a few folds of low amplitude (Figure 1) [e.g., Price et al., 1997]. Mosar et al. [2002] calculated spreading rates along each of the Reykjanes, Aegir and Mohns Ridges, showing that there was significant variation in spreading rates across the JMFZ. They suggested that this differential spreading was responsible for compressional inversion of the Vøring and Faeroe-Shetland Basins, rather than the Møre Basin.

[6] So as to investigate this idea more fully, we have developed a method for palinspastic reconstruction of oceanic domains. Instead of traditional Euler rotation poles, we have used an iterative least squares method, which minimizes the gaps or overlaps between conjugate magnetic anomalies. In this method, all segments of the NE Atlantic are free to spread at different rates. Our models provide new constraints on the style and timing of deformation along major oceanic fracture zones during seafloor spreading, as well as on the European Continental Margin.

\section{Geological Setting}

\subsection{Kinematics of the NE Atlantic Ocean}

[7] During the late Paleocene, Greenland and Eurasia separated, as seafloor spreading propagated northward out of the central North Atlantic [e.g., Pitman and Talwani, 1972; Srivastava and Tapscott, 1986; Vogt and Avery, 1974]. A triple junction existed between the North Atlantic and
Labrador Sea Ridges until the extinction of the latter at about 35 Ma [e.g., Vogt and Avery, 1974]. This extinction triggered a change in spreading direction between Europe and Greenland at about that time [e.g., Srivastava and Roest, 1999; Srivastava and Tapscott, 1986; Vogt and Avery, 1974]. After continental breakup ( $\sim 56 \mathrm{Ma})$ [e.g., Nunns, 1983], the mid-oceanic ridge between the margins of Greenland and Eurasia became offset to the east along the northern flank of the GIFR [Bott, 1985, 1987; Nunns, 1983]. Seafloor spreading occurred along the Aegir Ridge on the eastern side of the JMMC, which was part of Greenland at that time [e.g., Nunns, 1983]. However, rifting propagated northward from the Reykjanes Ridge into the southwestern part of the JMMC, after at least Chron 20 ( 44 Ma), leading to significant stretching of this microcontinent [Bott, 1985, 1987; Gaina et al., 2009; Müller et al., 2001; Nunns, 1983]. Between Chron $13(\sim 33 \mathrm{Ma})$ and Chron $6(\sim 20 \mathrm{Ma})$, the Aegir Ridge became extinct and a new spreading center, the Kolbeinsey Ridge, formed on the western side of the highly stretched JMMC, which separated totally from Greenland [Bott, 1985, 1987; Gaina et al., 2009; Müller et al., 2001; Nunns, 1983; Scott et al., 2005; Skogseid et al., 2000; Talwani and Eldholm, 1977; Unternehr, 1982]. Since Chron 6 , the Kolbeinsey Ridge has been the only active spreading center in the Jan Mayen Segment [e.g., Gaina et al., 2009]. There have been several models for the complex spreading history of the Jan Mayen Segment [Bott, 1985, 1987; Gaina et al., 2009; Nunns, 1983; Scott et al., 2005; Unternehr, 1982]. According to various authors, as the JMMC 


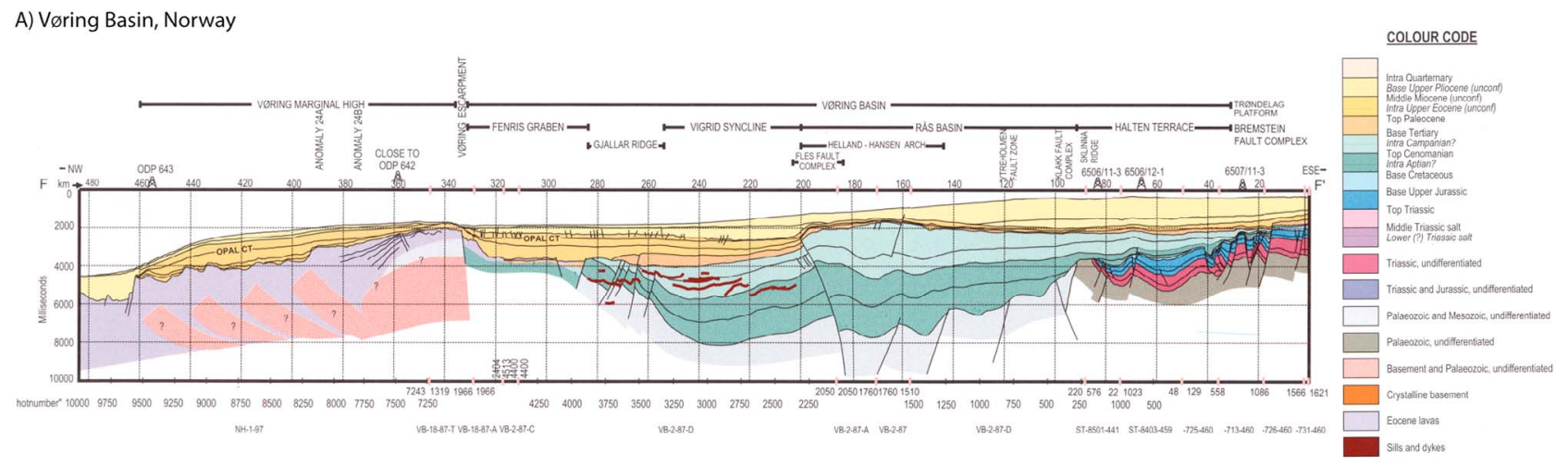

B) Wyville-Thomson and Ymir ridges, Faeroe - Rockall Plateau

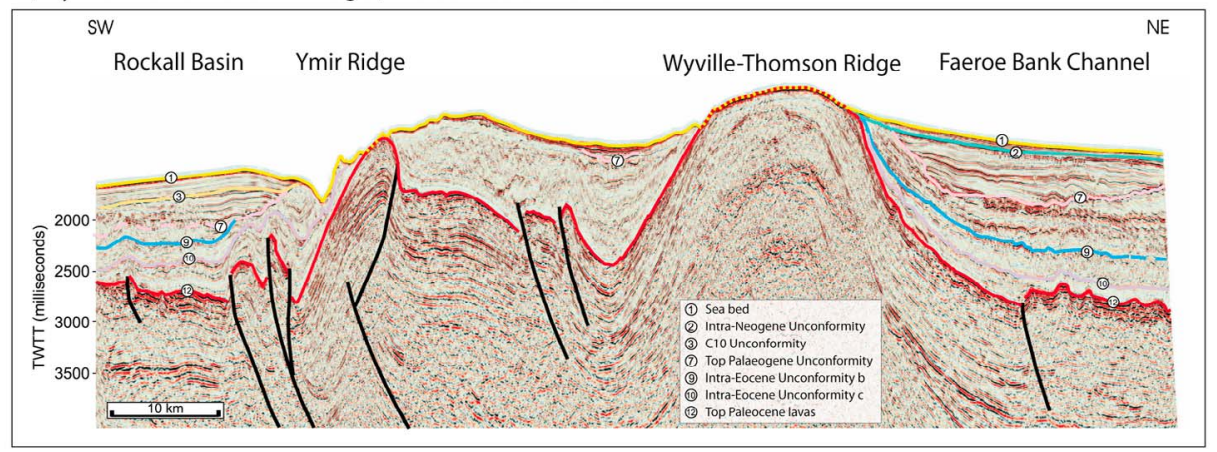

Figure 3. Interpreted seismic profiles across (a) Helland-Hansen Arch, in Vøring Basin, Norway, from Brekke [2000] and (b) Wyville-Thomson and Ymir Ridges, in Faeroe-Rockall Plateau, from Johnson et al. [2005]. Locations of profiles are on Figure 1.

separated from Greenland, it rotated counterclockwise by about $30^{\circ}$ and this resulted in fan-shaped seafloor spreading along the Aegir Ridge [Bott, 1987; Gaina et al., 2009]. However, misfits remain in reconstructions of conjugate magnetic anomalies of the Aegir Ridge [e.g., Gaina et al., 2009]. We have therefore used a palinspastic method of restoration in order to improve the fit between conjugate magnetic anomalies on this ridge.

\subsection{The NW European Continental Margin}

[8] By consensus, a "passive" margin [Mitchell and Reading, 1969], such as the NW European Continental Margin, develops in two stages. First, stretching of continental lithosphere leads to block faulting and tectonic subsidence. Second, the margin undergoes long-term thermal subsidence, but no more extensional faulting [McKenzie, 1978]. However, many authors have described postrift compressional structures (folds, reverse faults and reactivated normal faults) along the NW European Margin [Boldreel and Andersen, 1993; Brekke, 2000; Davies et al., 2004; Doré et al., 2008; Doré and Lundin, 1996; Hitchen, 2004; Johnson et al., 2005; Lundin and Doré, 2002; Løseth and Henriksen, 2005; Ritchie et al., 2003, 2008; Smallwood, 2004; Stoker et al., 2005; Tuitt et al., 2010]. Moreover, studies of fission tracks in apatite or zircon have revealed various Cenozoic episodes of uplift and exhumation in NW Europe [e.g., Anell et al., 2009; Hendriks et al., 2007; Holford et al., 2009; Japsen et al., 2010]. In contrast, the east Greenland margin was subject to extension and magmatism while the JMMC separated from Greenland [e.g., Price et al., 1997]. There is little evidence for postbreakup compressional deformation, except for minor low-amplitude folds of late Miocene age in the Trail Ø region [e.g., Price et al., 1997] and offshore NE Greenland [Hamann et al., 2005] (Figure 1). Postbreakup compressional structures developed more strongly at the SE ends of the JMFZ in the Vøring Basin, on the Norwegian Margin, and more widely on the FaeroeRockall Plateau (Figures 1 and 3) [e.g., Doré and Lundin, 1996; Johnson et al., 2005].

[9] On the Norwegian Margin, compressional doming, basin inversion and reverse faulting occurred predominantly within deep Cretaceous depocenters [Lundin and Doré, 2002]. In the Vøring Basin, Lundin and Doré [2002] described two phases of transpression (combination of strike-slip and transverse shortening) in (1) the middle Eocene to early Oligocene and (2) the early Miocene. These phases the authors held responsible for large domes and arches (e.g., the Ormen Lange Dome and Helland Hansen Arch), trending north or NNE (Figures 1 and 3). Around the Helland Hansen Arch, Løseth and Henriksen [2005] inferred a phase of compression in the middle to late Miocene (15-10 Ma), from seismic interpretation of the syntectonic Kai Formation. Doré and Lundin [1996] suggested that compressional domes formed by left-lateral reactivation of lineaments trending NW-SE, subparallel to the JMFZ or along it. In contrast, the Møre Basin contains no Cenozoic compressional structures [Brekke, 2000]. Mosar et al. [2002] suggested that a difference in spreading 
rates among the Mohns, Aegir and Reykjanes Ridges was responsible for the development of inversion structures in the Vøring Basin and on the Faeroes-Rockall Plateau, rather than in the Møre Basin.

[10] On the Faeroe-Rockall Plateau, compressional structures are different from those on the Norwegian Margin and they also vary in size, trend and shape [Tuitt et al., 2010]. North of the Faeroe-Shetland Basin, the trend of anticlines is predominantly NE-SW (e.g., the Fugløy Ridge), whereas in the south, the trend is mainly NW-SE (e.g., the Munkagrunnar Ridge) (Figures 1 and 3). On the southern part of the plateau (Hatton Bank), the trend varies from NE-SW (e.g., the Mid-Hatton Bank Fold Complex) to NNE-SSW (e.g., the North Hatton Bank Fold Complex) (Figure 1). Boldreel and Andersen [1998] inferred three main phases of compressional deformation, each resulting in a distinct structural trend: (1) a Paleocene to early Eocene phase, for structures trending WNW (e.g., the Wyville-Thomson Ridge), NNW (e.g., Munkagrunnar Ridge) or ENE (e.g., Fugløy Ridge); (2) an Oligocene phase, for folds trending NE to ENE, to the east of the Faeroe Islands and between the Faeroe Islands and Hatton Bank; and (3) a Miocene phase, for anticlines trending NW, perpendicular to the continental margin. More recent studies of seismic reflection data have shown that structures trending NE to ENE across the NE Faeroe-Shetland Basin developed mainly during the early Miocene to middle Miocene and may have continued to grow during early Pliocene to Recent times [Johnson et al., 2005; Ritchie et al., 2008, 2003]. However, there may have been an older (Eocene to Oligocene) phase of deformation on the Fugløy Ridge. South of the WTYR area, the Alpine dome formed during the Oligocene, whereas the North Hatton Bank Fold Complex grew in the middle Eocene to early Oligocene [Johnson et al., 2005; Ritchie et al., 2008, 2003]. Tuitt et al. [2010] described several compressional unconformities (late Paleocene to early Oligocene) on the FaeroeRockall Plateau.

[11] Among the mechanisms which may have accounted for these compressional structures are (1) the Alpine stress field [e.g., Brekke, 2000], (2) ridge push [Boldreel and Andersen, 1998; Doré and Lundin, 1996], (3) plumeenhanced ridge push [Lundin and Doré, 2002], (4) differential seafloor spreading and mantle drag [Mosar et al., 2002], (5) differential compaction [e.g., Stuevold et al., 1992], and (6) development of the Iceland Insular Margin [Doré et al., 2008]. These mechanisms are still subject to debate. In this paper, we investigate the possible effects of differential seafloor spreading.

\section{Data and Methods}

\subsection{Data Set}

[12] In the NE Atlantic there have been numerous geophysical surveys. Magnetic data sets are of good quality, but the identification of magnetic anomalies is problematic in some areas, such as around Iceland and along the GIFR (Figure 2). We have determined the positions of (1) fracture zones from the gravity data of Andersen et al. [2010] and Kimbell et al. [2005] and (2) isochrons from Gaina et al. [2009], Gernigon et al. [2009], Jones et al. [2002], Macnab et al. [1995], Maus et al. [2009], Olesen et al. [2007] and Skogseid et al. [2000]. The geographical coordinates of these fracture zones and isochrons are available in Data Set 1 in the auxiliary material. ${ }^{1}$

[13] We have assigned a spatial uncertainty of $5 \mathrm{~km}$ for the positions of both magnetic anomalies and fracture zones, as in previous studies [e.g., Gaina et al., 2009; Müller et al., 1999]. The positions and age (55.9 Ma) of the continentocean boundaries (COB) of Greenland and Europe are from Gaina et al. [2009] and Olesen et al. [2007]. Ages of magnetic anomalies are mean values for each identifiable isochron, according to the magnetic timescale of Cande and Kent [1995].

\subsection{Restoration Method}

[14] We have used an iterative least squares method for palinspastic reconstruction of the opening of the NE Atlantic Ocean. The method proceeds by minimizing gaps or overlaps between adjacent strips of oceanic crust, which follow magnetic anomalies (Figure 4). An early application of this method was to restore deformed surfaces, by minimizing gaps and overlaps between rigid elements [Cobbold, 1979]. Subsequent applications were to regions of strike-slip faulting [Audibert, 1991], normal faulting [Rouby et al., 1993] or reverse faulting [Arriagada et al., 2008; Bourgeois et al., 1997]. The method is purely geometric. For example, in a region of normal faulting, where a single fault offsets a stratigraphic horizon, the projection of the fault heave on a map defines a cutoff lens [Rouby et al., 1993, Figure 1]. The width of the lens is proportional to the fault heave. The least squares method minimizes the gaps (cutoff lenses) across normal faults on a structure-contour map of a given stratigraphic horizon. The first step before restoration is therefore to determine the positions and heaves of the normal faults. The result is a fault-block map, where faults (real or artificial) surround each block [Rouby et al., 1993, Figure 2], and each block is internally rigid. The second step is to define a stationary block, for reference purposes. An algorithm then minimizes the sum of the squares of the distances across cutoff lenses, with respect to unknown values of rigid translation and rotation for the remaining blocks [Rouby et al., 1993, Figures 4 and 5].

[15] The numerical procedure minimizes the sum $(D)$ of the squares of all distances across all cutoff lenses. This minimization generates a set of nonlinear equations, in terms of block translations and rotations. To solve these equations, the program uses an iterative method, similar to the Gauss-Seidel method [Audibert, 1991; Rouby et al., 1993]. A single iteration includes a sequence of operations: neighbor seeking, block translation and block rotation. The program repeats the iterations cyclically, until the equations have converged, according to a criterion $G$, a nondimensional parameter that represents the fractional area of gaps and overlaps:

$$
G=S_{g} / S_{b}
$$

where $S_{\mathrm{g}}$ is the total surface area of all gaps and overlaps, and $S_{\mathrm{b}}$ is the total surface area of all the blocks [Rouby et al., 1993]. A good approximation to $S_{\mathrm{g}}$ is

$$
S_{\mathrm{g}}=L^{*}(D / n)^{1 / 2}
$$

\footnotetext{
${ }^{1}$ Auxiliary material data sets are available at $\mathrm{ftp}: / / \mathrm{ftp}$.agu.org/apend/tec/ 2011tc003087. Other auxiliary material files are in the HTML. doi:10.1029/ $2011 \mathrm{TC} 003087$.
} 


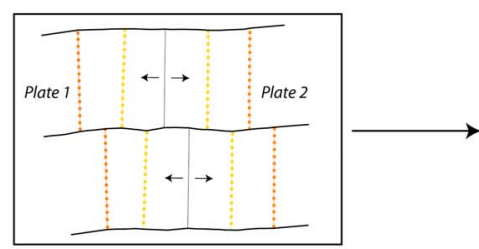

DATASET (map view)

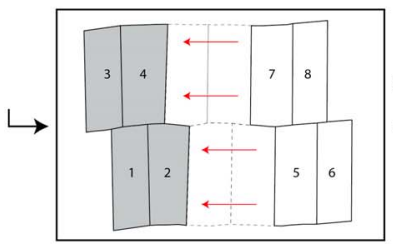

Block Map for restoration at time 1

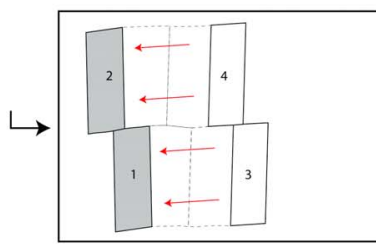

Block Map for restoration at time 2

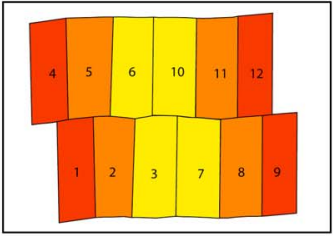

BLOCK MAP
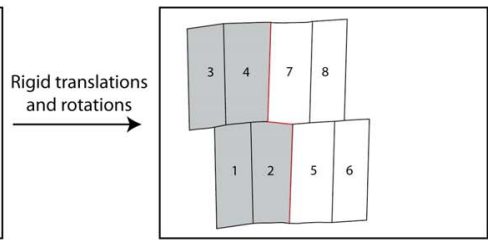

Restoration at time 1 after minimization of gaps and overlaps between the blocks
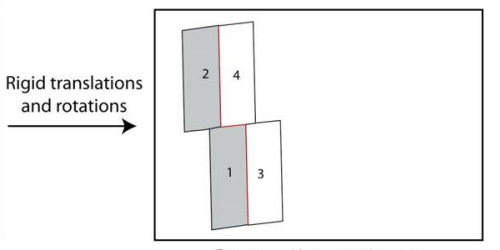

Restoration at time 2

after minimization of gaps and overlaps between the blocks

Figure 4. Method of restoration of the opening of an ocean.

where $L$ is the length of a line element, $n$ is the total number of line elements, and $(D / n)^{1 / 2}$ is the root-mean-square gap width [Rouby et al., 1993]. The program calculates $G$ and tests for convergence at the end of each iteration. The convergence is considered satisfactory when $G$ reaches a minimal value [Arriagada, 2004].

[16] In this study, we apply the method, not to restore surfaces between normal or reverse faults, but to fit conjugate magnetic anomalies of an oceanic domain and therefore to restore the opening of the NE Atlantic (Figure 4) [Le Breton, 2012]. The edges of the blocks are magnetic anomalies or fracture zones and the cutoff lenses represent the gaps between conjugate anomalies. Restoration is on a horizontal plane, rather than a spherical surface, and therefore some errors will arise [Le Breton, 2012]. We estimate them by comparing the initial and final lengths of blocks. For this purpose we use GPlates software [Boyden et al., 2011], which takes into account the sphericity of the Earth to calculate distances and allows superposition of the blocks. We estimate these uncertainties to be, at most, $9 \mathrm{~km}$ for the Mohns Segment, $5 \mathrm{~km}$ for the Jan Mayen Segment and $4.5 \mathrm{~km}$ for the Reykjanes Segment. Because there is little evidence of postbreakup compressional deformation on the Greenland Margin, we assume that the Greenland plate is rigid and stationary. In contrast, we allow the European plate to be mobile and deformable.

\subsection{Block Map of the NE Atlantic}

[17] We have subdivided the NE Atlantic region into a finite number of rigid oceanic blocks, between magnetic anomalies and fracture zones (Figure 5). In the Mohns and Reykjanes Segments, the pattern of magnetic anomalies and fracture zones is easily identifiable from Chron 5 to Chron 24 .
In the Jan Mayen Segment, the pattern of magnetic anomalies is identifiable on the eastern side of the Aegir Ridge, from Chron 13 to Chron 24, and along the Kolbeinsey Ridge, from Chron 6 to the present day. However, it is more difficult to identify the magnetic anomaly of Chron 8 in these two areas (Figure 2). Magnetic anomalies are also more difficult to interpret around the JMMC. We therefore used information on the structural development of the JMMC from Bott [1985, 1987], Gaina et al. [2009], Gernigon et al. [2009], Mjelde et al. [2008], Nunns [1983], and Unternehr [1982], so as to define the blocks around the JMMC. From these studies, we estimated that approximately $50 \%$ of the JMMC consists of stretched continental crust, especially in the southern part of the JMMC and in its conjugate part on the Greenland margin. We therefore defined 8 thin continental blocks on the western side of the JMMC and 8 others on the eastern side of Greenland, between the magnetic anomaly at Chron 8 and the COB, in order to take into account the progressive continental stretching along the JMMC, and its subsequent counter clockwise rotation [e.g., Bott, 1985, 1987; Gaina et al., 2009; Nunns, 1983] (Figure 5). The 16 blocks thus mimic the stretched continental crust of the JMMC, rather than the oceanic crust (as do the other blocks).

[18] Two large stationary blocks bound the block map on its northern and southern sides (Figure 5), one north of the Mohns Segment, along the Greenland and Senja FZ, and another one south of the Reykjanes Segment, along the Charlie Gibbs FZ. Their purpose was to constrain the opening of the NE Atlantic, coherently with the opening of the Central Atlantic Ocean in the south and the Boreas Basin in the north. We determined the successive positions of these two constraining blocks, relative to a stationary Greenland 


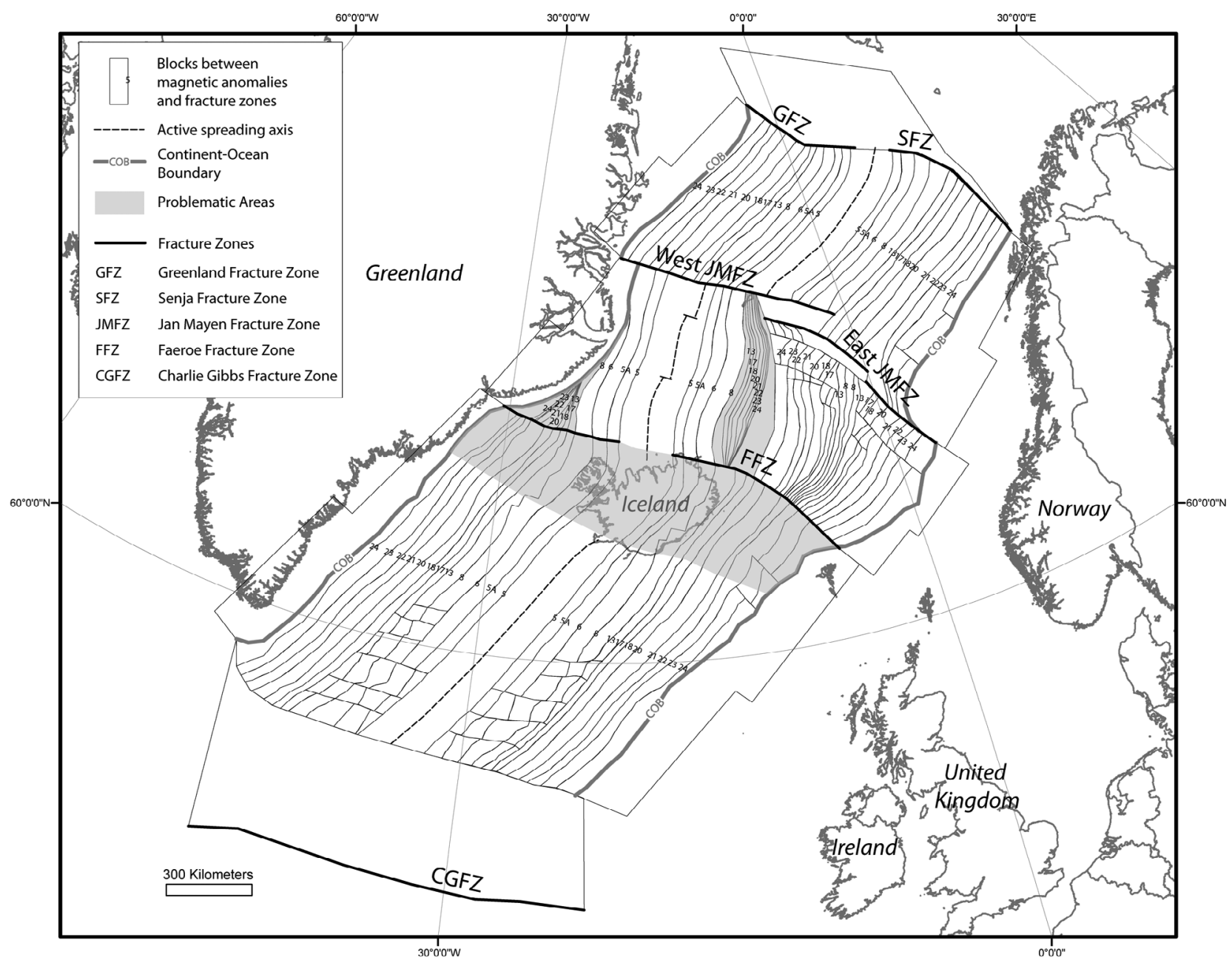

Figure 5. Block map for restoration of NE Atlantic. Isochrons and fracture zones bound blocks. Map projection is Universal Transverse Mercator (UTM, WGS 1984, zone 27N).

plate, using the EarthByte model (rotations poles are from Gaina et al. [2002]) and the Gplates software [Boyden et al., 2011]. During each stage of restoration, the two stationary blocks impeded northward or southward displacement of mobile blocks along the ridge. The JMFZ separates the Mohns and Jan Mayen Segments, and the Faeroe Fracture Zone (FFZ) separates the Jan Mayen and the Reykjanes Segments (Figure 5). In this method, all segments of the NE Atlantic are free to spread at different rates and in different directions, so that relative displacements between segments will occur exclusively along the two oceanic fracture zones (JMFZ and FFZ).

[19] At each stage of the restoration, we used the easternmost (external) blocks of each zone to calculate mean displacement rates. This yielded spreading rates along each ridge and relative displacements between each segment through time, along the JMFZ and FFZ. The external blocks along the COB have artificial edges (Figure 5), which serve to calculate, after the reconstructions, best fit rotation poles for each ridge and for each magnetic anomaly (Figure 6). Chang [1987], Stock et al. [1990], Jurdy and Stefanick [1987] and Kirkwood et al. [1999] developed a method, based on the criterion of fit of Hellinger [1981], to estimate poles for finite plate motions and their uncertainties. In our study, we used the program Hellinger1 from Kirkwood et al. [1999] to estimate best fit rotation poles.

[20] Using this method, we tested two models. The algorithm is the same for both models; however we modified the input parameter that defines which blocks are "neighboring." The algorithm will then minimize the gaps and overlaps between those blocks. In Model 1, the algorithm minimizes the gaps between adjacent magnetic anomalies of each segment, but not the gaps or overlaps across oceanic fracture zones; whereas, in Model 2, the algorithm minimizes the gaps between adjacent anomalies and also the gaps or overlaps across oceanic fracture zones.

\section{Results}

\subsection{Reconstruction of the NE Atlantic Relative to a Stationary Greenland Plate}

[21] We describe two kinematic models of Europe, relative to a stationary Greenland plate. These models allow displacements on both sides of the Aegir Ridge during the 


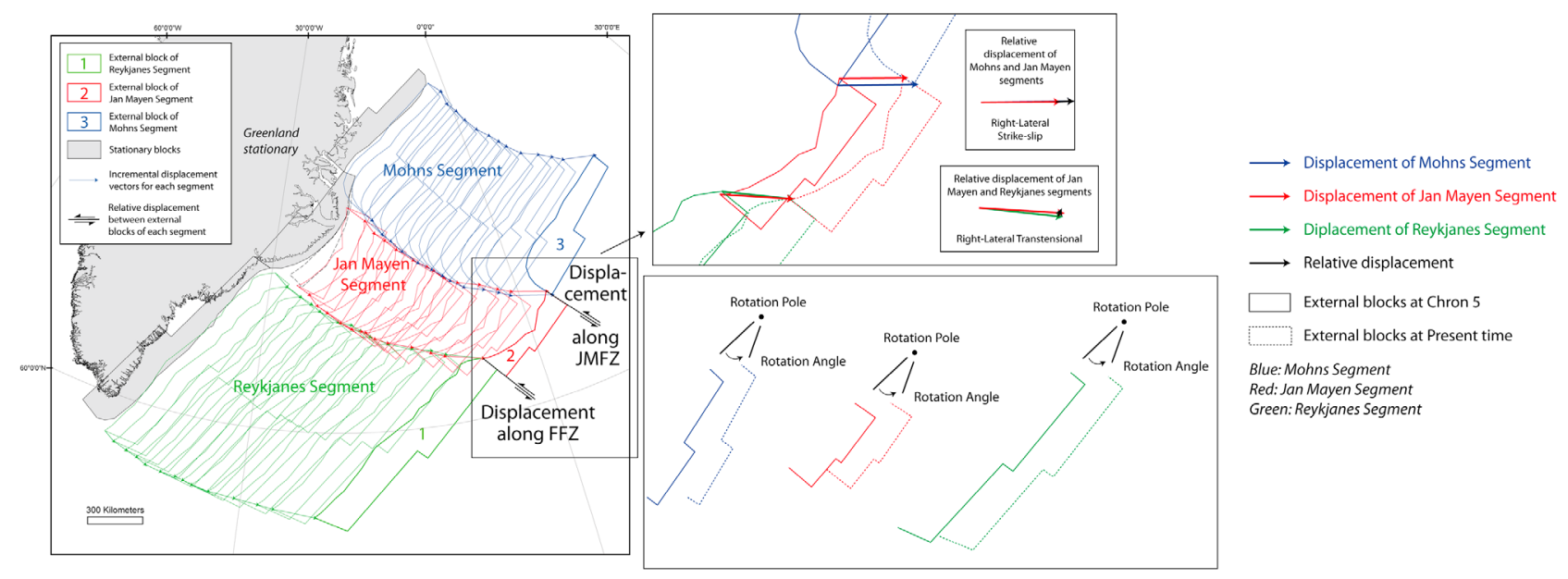

Figure 6. Method for determining relative displacement vectors between segments along JMFZ and FFZ and rotation poles for each ridge system, for example, between Chron 5 and present time. Map projection is Universal Transverse Mercator (UTM, WGS 1984, zone 27N).

reconstructions in order (1) to take into account the formation and clockwise rotation of the JMMC, as described by Bott [1987], Gaina et al. [2009], Nunns [1983] and Unternehr [1982], and (2) to obtain a good fit between adjacent magnetic anomalies on the Aegir Ridge. For both models, the 13 stages of restoration (including $G$ values for each restoration), from 55.9 Ma to Chron $5(10.3 \mathrm{Ma})$, and the best fit rotation poles and their uncertainties, for each spreading system, are all in Text S1 in the auxiliary material.

[22] Both models display good fits of magnetic anomalies for all ridge segments ( $G$ values range from 0.0016 to 0.0043 for Model 1 and from 0.0007 to 0.0058 for Model 2). Model 1 provides better fits of magnetic anomalies (mean $G=0.0025$ ), but allows significant gaps and overlaps across transform faults $(\sim 2.4 \%$ of the whole surface). Model 2 minimizes the gaps and overlaps across transform faults ( $\sim 1.4 \%$ of the whole surface), but this reduces the goodness of fit between magnetic anomalies (mean $G=0.0035$ ). However, we consider that the fit is acceptable, by comparison with the uncertainties in the data set and the errors in the restoration method. Restorations from Chron 5 $(10.3 \mathrm{Ma})$ to Chron $13(33.3 \mathrm{Ma})$ are very similar for models 1 and 2, the main difference between them being for restorations between Chron 13 (33.3 Ma) and Chron 24 (52.69 Ma), when the Aegir Ridge was active. For both models, the JMMC rotates counter clockwise $\left(\sim 25^{\circ}\right.$ in Model 1 and $\sim 30^{\circ}$ in Model 2) from breakup to Chron 13 (33.3 Ma) (Text S1). However, between Chron 13 (33.3 Ma) and Chron 24 (52.69 Ma), the eastern side of the Aegir Ridge rotates clockwise more strongly in Model 1 than in Model 2, resulting in significant gaps and overlaps across transform faults in Model 1. The final restorations at 55.9 Ma are very similar for both models and generate significant offsets between oceanic segments along the FFZ and the JMFZ. Previous studies [Bott, 1985, 1987; Nunns, 1983; Scott et al., 2005] also predicted such offsets along the FFZ and JMFZ.

\subsection{Direction of Spreading}

[23] The incremental displacement vectors of the eastern external blocks, which represent the European COB, illustrate the motion of Europe relative to Greenland for 13 stages, from 55.9 Ma to the present time (Figure 7). Both Model 1 and Model 2 produce offsets of the COB at 55.9 Ma: approximately $140 \mathrm{~km}$ along the FFZ, between the Reykjanes and Jan Mayen Segments, and $70 \mathrm{~km}$ along the JMTZ, between the Jan Mayen and Mohns Segments.

[24] For both models also, the directions of spreading of the Reykjanes and Mohns Segments are relatively similar (Figure 7). In Model 1, the main changes in spreading direction are at Chron 21 (47.1 Ma) and Chron 20 (43.2 Ma), along the Reykjanes Ridge, and at Chron 8 (26.4 Ma) and Chron 5 (10.3 Ma), along the Mohns Ridge. In Model 2, the main changes in spreading direction are at Chron 18 (39.4 Ma), along the Reykjanes Ridge, and at Chron 24 (52.9 Ma), Chron 8 (26.4 Ma) and Chron 5 (10.3 Ma), along the Mohns Ridge. For both models, the Reykjanes and Mohns Ridges have similar spreading histories.

[25] The main difference between the two models is the direction of spreading in the Jan Mayen Segment, between Chron 24 (52.9 Ma) and Chron 13 (33.3 Ma), when the Aegir Ridge was active. In Model 1, the spreading direction of the Jan Mayen Segment varies through time and is significantly different from those of the nearby Reykjanes and Mohns Segments, between Chron 24 (52.9 Ma) and Chron 13 (33.3 Ma) (Figure 7). Also, the displacements are greater in the northern part of the segment, than they are in the southern part, especially between Chron 20 (43.2 Ma) and Chron 13 (33.3 Ma). Seafloor spreading is thus asymmetric along the Jan Mayen Segment and results in significant clockwise rotation $\left(\sim 20^{\circ}\right)$ of the European COB of the Jan Mayen Segment at that time. The differences in spreading directions between the three segments generated significant gaps and overlaps along the FFZ and JMFZ (Figure 7). In Model 2, the direction of spreading of the Jan Mayen Segment is also different from those of the Reykjanes and Mohns Segments between Chron 23 (51.3 Ma) and Chron 13 (33.3 Ma), but less so than in Model 1. Spreading is asymmetric along the Jan Mayen Segment, but the resulting clockwise rotation of the European COB of this segment is small $\left(\sim 10^{\circ}\right)$, by comparison with that of Model 1 $\left(\sim 20^{\circ}\right)$. Therefore in Model 2, relative displacements along 


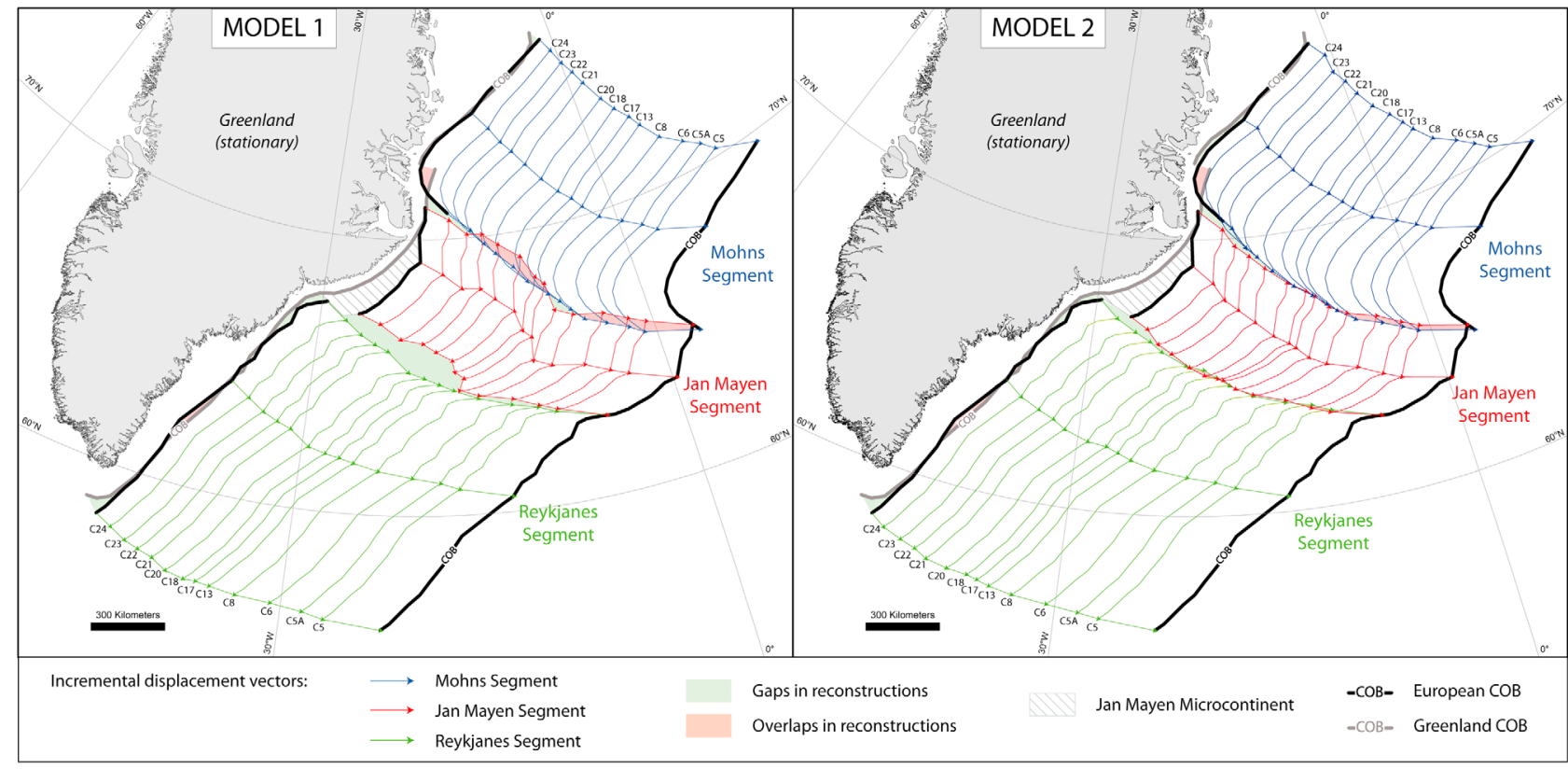

Figure 7. Incremental displacement vectors for material points at ends of segments (Mohns, Jan Mayen and Reykjanes) and positions of European continent-ocean boundary relative to stationary Greenland plate, from 55.9 Ma to present time, for Model 1 (involving minimization of gaps between conjugate anomalies) and Model 2 (involving minimization of gaps between conjugate anomalies and between segments). Notice remaining gaps and overlaps along fracture zones. Map projection is Universal Transverse Mercator (UTM, WGS 1984, zone 27N). For ages, see Figure 2.

the FFZ and JMFZ are smaller and more purely strike slip than they are in Model 1 (Figure 7).

[26] Gaps in reconstructions imply that compressional deformation should have occurred during seafloor spreading; conversely, overlaps imply that deformation was extensional. Thus, Model 1 predicts large compressional deformation (up to $170 \mathrm{~km}$ of shortening) along the FFZ, but extensional deformation (at most, $80 \mathrm{~km}$ of stretching) along the JMFZ. Previous studies of these fracture zones, using geophysical data, have not revealed such styles of deformation [e.g., Bohnhoff, 2004; Gernigon et al., 2009]. Deformation is smaller in Model 2 (at most, $25 \mathrm{~km}$ and $10 \mathrm{~km}$ of shortening along the FFZ and JMFZ, respectively). Therefore in what follows we will focus the discussion on the results of Model 2.

\subsection{Spreading Rates}

[27] For Model 2, we have calculated spreading rates for each ridge system, from the mean displacement rates of external blocks (Figure 8). Since 10.3 Ma, the average spreading rates are $21 \mathrm{~mm} / \mathrm{yr}$ for the Reykjanes Ridge, $18 \mathrm{~mm} / \mathrm{yr}$ for the Kolbeinsey Ridge and $20 \mathrm{~mm} / \mathrm{yr}$ for the Mohns Ridge (Figure 8). These values are in good agreement with the previous estimates of Mosar et al. [2002] of $21 \mathrm{~mm} / \mathrm{yr}$ for the Reykjanes Ridge and $18 \mathrm{~mm} / \mathrm{yr}$ for the Kolbeinsey Ridge, but are slightly higher than their estimate of $16 \mathrm{~mm} / \mathrm{yr}$ for the Mohns Ridge.

[28] Spreading rates for the Reykjanes and Mohns Ridges are high (55 and $53 \mathrm{~mm} / \mathrm{yr}$, respectively), when seafloor spreading began in the early Eocene. They progressively decrease (to 15 and $12 \mathrm{~mm} / \mathrm{yr}$, respectively) until Chron 8 , in the late Oligocene, before increasing again, during the late Oligocene and Miocene, up to the present-day rates of 21 and $20 \mathrm{~mm} / \mathrm{yr}$, respectively (Figure 8). Mosar et al. [2002] have described such a spreading history for all ridges, and Torsvik et al. [2001] noticed the decrease in spreading rate from the early Eocene to Chrons 13/8 in absolute plate velocities for the North Atlantic. In our Model 2, spreading along the Aegir Ridge has a similar history. Spreading rates are high (up to $38 \mathrm{~mm} / \mathrm{yr}$ ) in the early Eocene, decrease significantly (down to $9 \mathrm{~mm} / \mathrm{yr}$ ) between Chron 20 (47.1 Ma) and Chron 21 (43.2 Ma), and finally increase (up to $14 \mathrm{~mm} / \mathrm{yr}$ ) between Chron 17 (36.6 Ma) and Chron 13 (33.3 Ma) (Figure 8). Seafloor spreading ceased along the Aegir Ridge between Chron 13 and Chrons 8 to 6 and started along the Kolbeinsey Ridge. Spreading rates progressively increased along the Kolbeinsey Ridge, up to the present-day rate of $18 \mathrm{~mm} / \mathrm{yr}$.

[29] The mean spreading rate (average value along the ridge) is lower for the Aegir Ridge than it is for the Reykjanes and Mohns Ridges. As we mentioned before, the displacement vectors of the Jan Mayen Segment indicate asymmetric spreading between Chron 23 (51.3 Ma) and Chron 13 (33.3 Ma) (Figure 7). At that time, only the Aegir Ridge is active in this segment, so we calculated spreading rates at the northern and southern ends of this ridge (Figure 8). Spreading rates were up to $16 \mathrm{~mm} / \mathrm{yr}$ higher at the northern end of the Aegir Ridge than they were at the southern end (Figure 8). Mosar et al. [2002] described such a difference in spreading rates across the Aegir Ridge. They 


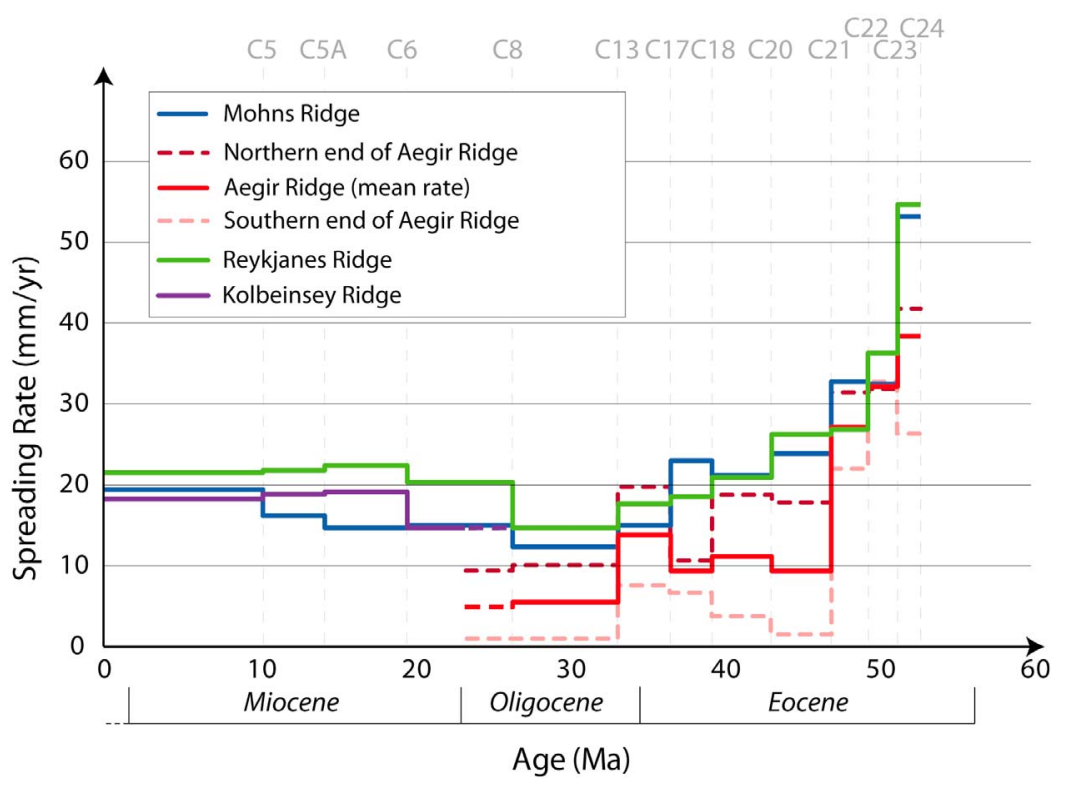

Figure 8. Spreading rates for Mohns Ridge, Aegir Ridge, Reykjanes Ridge and Kolbeinsey Ridge (Model 2). Dashed lines represent rates of spreading for northern and southern ends of Aegir Ridge.

correlated it with counterclockwise rotation of the JMMC during its separation from Greenland. In contrast, our Model 2 predicts both counterclockwise rotation $\left(\sim 30^{\circ}\right)$ of the JMMC and clockwise rotation $\left(\sim 10^{\circ}\right)$ of the eastern side of the Aegir Ridge (Text S1 and Figure 7).

\subsection{Deformation on the Margin Around Transfer Zones}

[30] In Model 2, differences in direction and rate of spreading along the Reykjanes, Mohns and Aegir/Kolbeinsey Ridges generate relative displacements along the JMFZ and FFZ (Figure 7). To visualize deformation on the margin, we have taken the European COB at 55.9 Ma and superimposed it (so as to coincide in position and average orientation) on the present-day European COB (Figure 9). The Reykjanes, Jan Mayen and Mohns Segments have undergone differential displacements and rotations, which reach maximal values against the transfer faults $(\sim 47 \mathrm{~km}$ for the Reykjanes Segment and $\sim 93 \mathrm{~km}$ for the Jan Mayen Segment, against the FFZ; $\sim 126 \mathrm{~km}$ for the Jan Mayen Segment and $\sim 52 \mathrm{~km}$ for the Mohns Segment, against the JMFZ). Along the Jan Mayen Segment, the direction of relative displacement reverses, from eastward in the north to westward in the south. Relative rotations are clockwise $\left(\sim 5^{\circ}\right)$ for the Reykjanes Segment, clockwise for the Jan Mayen Segment $\left(\sim 15^{\circ}\right.$ for the northern part, $\sim 5^{\circ}$ for the southern part) and counterclockwise $\left(\sim 5^{\circ}\right)$ for the Mohns Segment. Relative displacements along the FFZ $(\sim 140 \mathrm{~km})$ and JMFZ $(\sim 74 \mathrm{~km})$ imply left-lateral slip (Figure 9).

[31] For each stage in the restoration, we have drawn the relative displacement vectors between each segment (Figure 6). Then, from these vectors, we have estimated the total and incremental relative displacements between the three oceanic segments, along the JMFZ and FFZ (Figure 10). Displacements of less than $10 \mathrm{~km}$ are smaller than the uncertainties in the data set and the restoration method. The total relative displacements between the three oceanic segments imply leftlateral transpressional deformation (strike-slip and transverse shortening) around both the JMFZ (72 km) and the FFZ $(144 \mathrm{~km})$, from $55.9 \mathrm{Ma}$ to the present day. The amount of relative displacement, the sense of slip and the style of deformation along the JMFZ and FFZ vary through time (Figure 10).

[32] Along the JMFZ, a long period of left-lateral strike slip occurs between Chron 8 (26.4 Ma) and Chron 5 $(10.3 \mathrm{Ma})$. The style of deformation is dominantly strike slip, except between Chron 13 (33.3 Ma) and Chron 8 (26.4 Ma), when it is transpressional. The amount of displacement varies from $10 \mathrm{~km}$ to $75 \mathrm{~km}$. Model 2 predicts two periods of strike slip: (1) during the early Eocene, between 55.9 Ma and Chron 22 (49.4 Ma) and (2) from the late Eocene (39.4 Ma) to the present time.

[33] Along the FFZ, Model 2 predicts (1) 25 to $31 \mathrm{~km}$ of left-lateral displacement during the early Eocene, from 55.9 Ma to Chron 23 (51.3 Ma), and (2) 20 to $45 \mathrm{~km}$ of mainly left-lateral strike slip from the middle Eocene (Chron 22, 49.4 Ma) to late Oligocene (Chron 8, 26.4 Ma). Relative displacement occurs also during the Mio-Pliocene but more episodically: $21 \mathrm{~km}$ of transpressional displacement between Chron 6 (19.6 Ma) and Chron 5A (14.2 Ma), and $10 \mathrm{~km}$ of right-lateral transtensional displacement (strike-slip and transverse stretching) from Chron 5 (10.3 Ma) to the present time. The sense of slip along the FFZ is mostly left lateral, and the style of deformation varies through time. However, Model 2 predicts a long period of strike-slip deformation between Chron 22 (49.4 Ma) and Chron 8 (26.4 Ma).

[34] In summary, Model 2 predicts (1) a period of mainly left-lateral slip along both the JMFZ and the FFZ, at the beginning of seafloor spreading during the early Eocene (from 55.9 Ma to 51.3/49.4 Ma), and (2) a longer period of left-lateral slip along the FFZ, between Chron $21(47.1 \mathrm{Ma}$, mid-Eocene) and Chron 8 (26.6 Ma, late Oligocene), and 


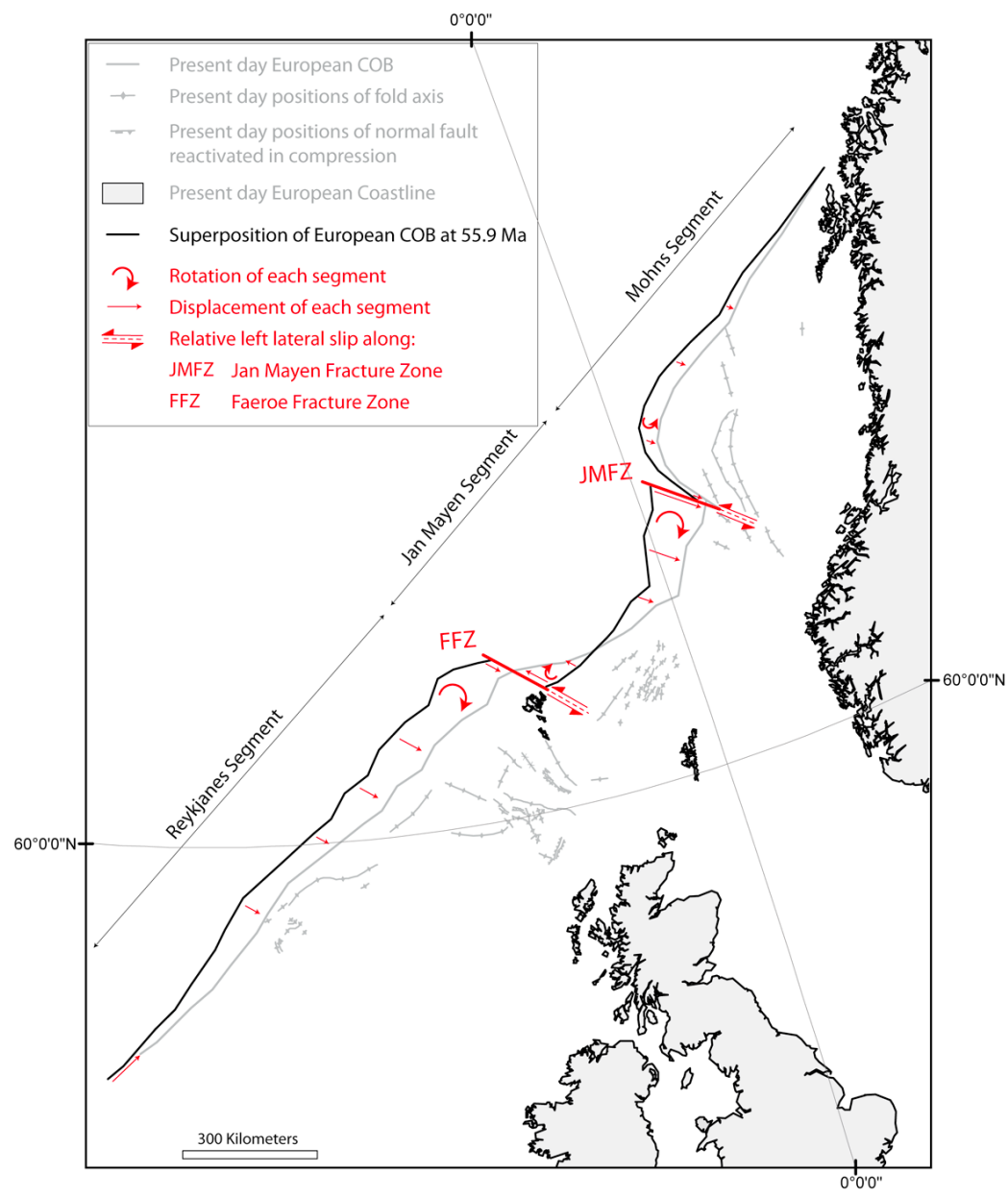

Figure 9. Relative shapes of (1) European $\mathrm{COB}$ at $55.9 \mathrm{Ma}$ (Model 2) and (2) present-day European $\mathrm{COB}$, margin and coastline. For visual comparison of shapes, we have made ends of COB segments to coincide. Arrows indicate relative rotation of each segment, varying displacement vectors along it, and amount of left-lateral slip along JMFZ and FFZ. These boundary displacements may account for patterns of compressional structures on European margin, next to COB (see text for details). Map projection is Universal Transverse Mercator (UTM, WGS 1984, zone 27N).

along the JMFZ between Chron 17 (36.6 Ma, late Eocene) and Chron 5 (10.3 Ma, late Miocene) (Figure 10).

\section{Discussion}

\subsection{Differential Seafloor Spreading and Deformation on the Adjacent Continental Margin}

[35] Mosar et al. [2002] attributed asymmetric seafloor spreading to an asymmetric flow pattern in the asthenosphere that causes differential mantle drag [Forsyth and Uyeda, 1975]. Our Model 2 predicts differences in direction and rate of spreading, between the Reykjanes, Aegir/ Kolbeinsey and Mohns Ridges, which may have deformed the adjacent continental margin (Figures 8 and 10).

[36] We have compared the timing of displacements along the JMFZ and FFZ, according to Model 2, with the history of inversion structures on the Norwegian Margin and the Faeroe-Rockall Plateau, respectively (Figure 10). In general, periods of relative displacements along the JMFZ and FFZ correlate well with periods of inversion on the NW European Margin (Figure 10).

[37] On the Norwegian Margin, compressional structures developed during the late Eocene and early Oligocene and mainly during the Miocene. These two periods coincide with the main periods of left-lateral strike slip along the JMFZ, between Chron 17 and Chron 13 (late Eocene to early Oligocene) and between Chron 8 and Chron 5 (Miocene) (Figure 10). Our results are consistent with the hypothesis of Doré and Lundin [1996] that compressional domes in the Vøring Basin formed by left-lateral reactivation of NW-SE trending lineaments at the SE end of the JMTZ. We infer from our Model 2 that this left-lateral deformation was due to differential spreading between the Mohns and Jan Mayen Segments.

[38] On the Faeroe-Rockall Plateau, compressional structures developed mainly during the Eocene to late Oligocene [Johnson et al., 2005; Tuitt et al., 2010], when Model 2 predicts left-lateral strike slip along the FFZ between Chron 21 and Chron 8 (47.1 to $26.6 \mathrm{Ma}$, mid-Eocene to late 


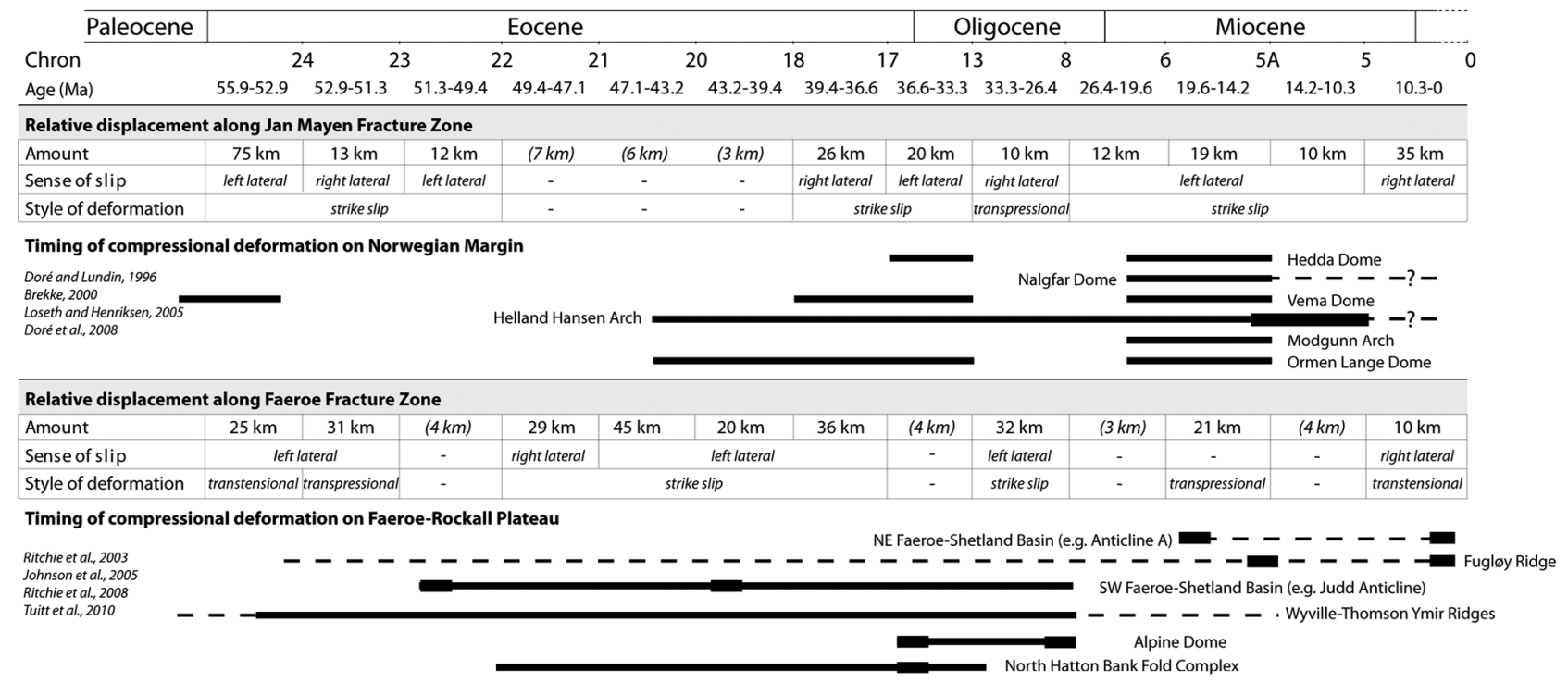

Figure 10. Relative displacement, sense of slip and style of deformation along JMFZ and FFZ from 55.9 Ma to present time, from relative displacement vectors between segments (Model 2). Timing of compressional deformation on Norwegian Margin is from Brekke [2000], Doré et al. [2008], Doré and Lundin [1996], Løseth and Henriksen [2005] and on Faeroe-Rockall Plateau from Johnson et al. [2005], Ritchie et al. [2008, 2003], Tuitt et al. [2010]. Positions of inversion structures are on Figure 11.

Oligocene) (Figure 10). Rotation and northward displacement of the Reykjanes Segment and left-lateral strike slip along the FFZ (Figure 9) may have generated constrictional deformation, for which the principal directions of shortening trend approximately N-S and E-W in the area south of the Faeroe Islands. Moreover, a series of NW trending transfer zones, subparallel to the FFZ, segment the NE Atlantic margin [Kimbell et al., 2005]. Left-lateral slip along the FFZ may have propagated also along these fracture zones. Constrictional deformation and left-lateral strike slip along NW trending fracture zones could have generated inversion structures of various trends (from NW-SE to NE-SW), as on the Faeroe-Rockall Plateau (Figures 1 and 9). Moreover, this deformation may have reactivated preexisting structures on the Faeroe-Rockall Plateau, either of Lewisian age (trending NW-SE, N-S and E-W) or of Caledonian age (trending NE-SW) [e.g., Tuitt et al., 2010].

[39] On the NE Faeroe-Shetland Basin, compressional structures trend NE to ENE (Figures 1 and 9). Ritchie et al. [2003] suggested that left-lateral slip along NW trending transfer zones, subparallel to the FFZ, was responsible for the development of NE to NNE trending folds in the NE Faeroe-Shetland Basin. However, Model 2 predicts leftlateral displacement along the FFZ during the Eocene and Oligocene, but not during the Miocene, whereas the inversion structures in this area developed mainly during the early Miocene to middle Miocene and from early Pliocene to Recent times (Figure 10) [Johnson et al., 2005; Ritchie et al., 2008, 2003]. Model 2 predicts instead transpressional deformation along the FFZ in the early Miocene (Chrons 6-5A, 19.6-14.2 Ma) and right-lateral transtensional deformation along the FFZ in the late Miocene and Pliocene (Chron 5A, $10.3 \mathrm{Ma}$, to present time) (Figure 10). The significant period of left-lateral displacement along the FFZ during the Eocene and the Oligocene has probably initiated some of the NE trending structures in this area, such as the Fugløy Ridge (Figures 1 and 10). However, during the Miocene and the Pliocene, there is no clear relationship between the relative displacement along the FFZ and the development of the NE to ENE trending structures in the NE Faeroe-Shetland Basin.

\subsection{Influence of the Iceland Mantle Plume}

[40] To examine the possible influence of the Iceland Mantle Plume on differential seafloor spreading, we have reconstructed the positions of the Iceland Mantle Plume, the NW European Continental Shelf and the JMMC, relative to a stationary Greenland plate and according to the stationary hot spot model of Lawver and Müller [1994] and the moving hot spot model of Mihalffy et al. [2008]. This we have done for four periods: (1) late Paleocene (55.9 Ma, and Figure 11a), (2) late Eocene to early Oligocene (Chron 17, 36.6 Ma, and Figure 11b), (3) early Miocene (Chron 6, 19.6 Ma, and Figure 11c) and (4) present time (Figure 11d).

[41] Magmatism was widespread throughout the North Atlantic during the Paleogene, accounting for a large Cenozoic igneous province [e.g., Saunders et al., 1997]. This North Atlantic Igneous Province (NAIP) extends from Baffin Island to the British Isles (Figure 11d) [e.g., Lawver and Müller, 1994; Saunders et al., 1997; Storey et al., 2007]. The Iceland plume is an obvious candidate for explaining the NAIP [e.g., White and McKenzie, 1989]. We have illustrated the track of the Iceland mantle plume for two models (Figure 11): (1) the stationary hot spot model of Lawver and Müller [1994] and (2) the moving hot spot model of Mihalffy et al. [2008]. According to the model of Lawver and Müller [1994], the Icelandic hot spot was beneath Greenland after breakup at Chron 24 (52.9 Ma, and Figure 11a), then beneath the eastern Greenland Margin, west of the JMMC, around $35 \mathrm{Ma}$, and afterward beneath the axis of the Reykjanes Ridge, since approximately 25 Ma. 

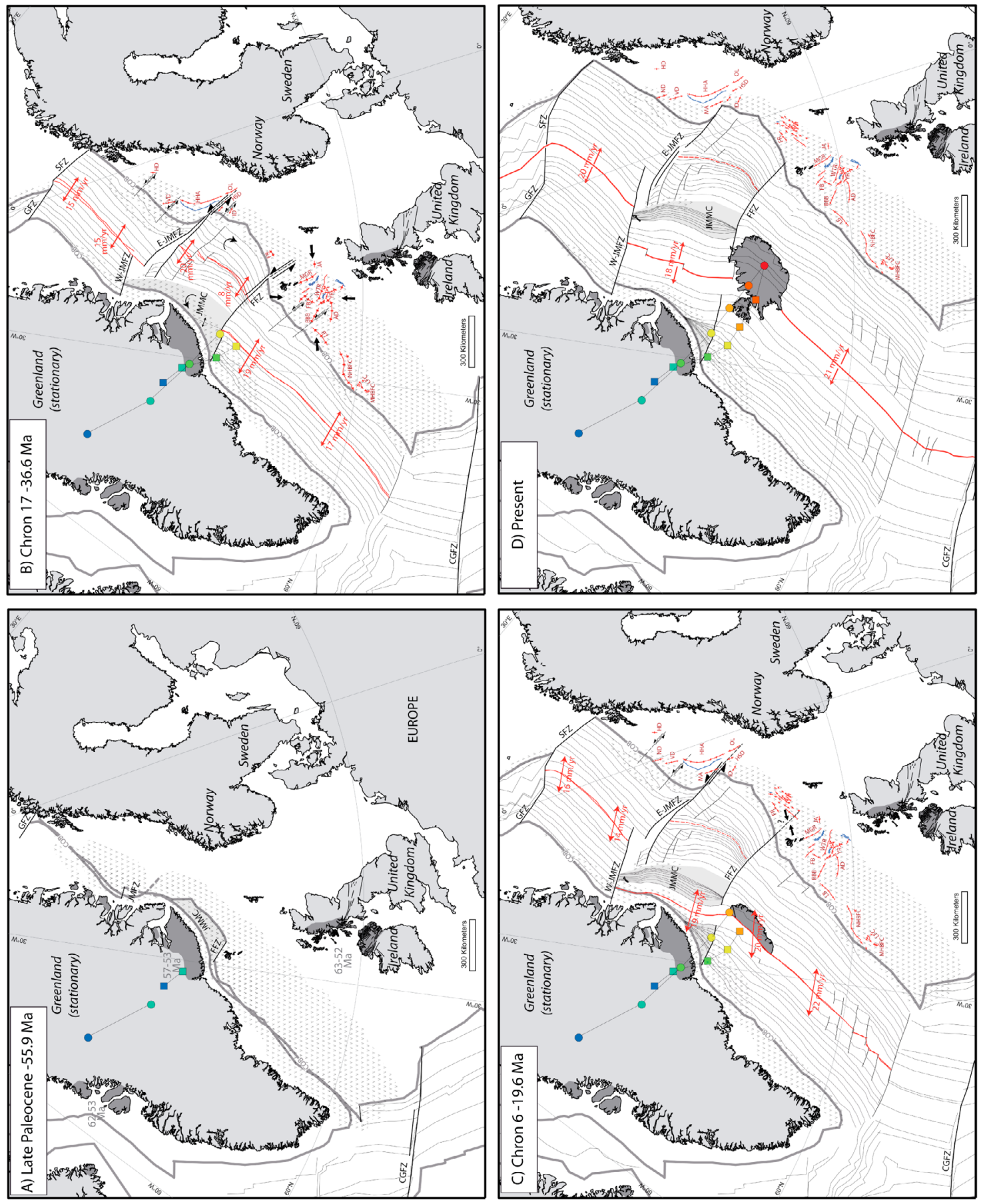

$=$

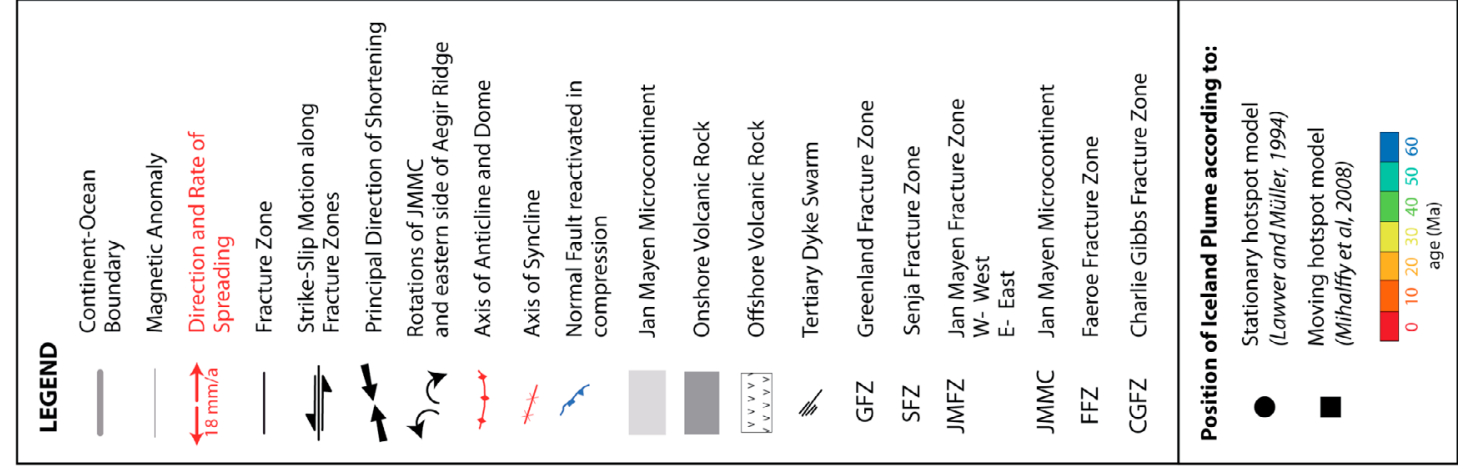


The mantle plume was closer to the NE Atlantic Ridge according to the moving hot spot models of Mihalffy et al. [2008], than it was according to the stationary hot spot model (Figure 11d).

[42] The Jan Mayen Segment had a complex spreading history in the Eocene and the Oligocene: (1) progressive separation of the JMMC, (2) counterclockwise rotation of the JMMC, (3) clockwise rotation of the eastern side of the Aegir Ridge (Figure 11b), and (4) later ridge jump from the Aegir Ridge to the Kolbeinsey Ridge in the late Oligocene to early Miocene (Figure 11c). We follow previous studies [e.g., Gaina et al., 2009; Müller et al., 2001] in suggesting that the position of the plume head in the vicinity of the Jan Mayen Segment (Figure 11b) generated this plate readjustment. During the Miocene, the plume head was beneath the Reykjanes Ridge (Figure 11c) and the resulting volcanic activity formed the Iceland Plateau [Doré et al., 2008]. Doré et al. [2008] suggested that this high plateau generated enough stress to deform adjacent margins in the Miocene, and that the Aegir Ridge would have behaved as a shield for the Møre Basin between the Iceland Plateau and the Vøring Basin, where inversion features developed. We suggest moreover that the Iceland Mantle Plume could have generated a radial pattern of compressive stress trajectories, responsible for shear stress along transform faults. In the model of Lawver and Müller [1994] and the moving hot spot model of Mihalffy et al. [2008], the Iceland Plume Head is south of the FFZ, therefore shear stress should be left lateral along both the FFZ and JMFZ. By comparison with Model 2 , the two main periods of left-lateral relative displacement along the FFZ and the JMFZ are compatible with the shear stress that arises when the Iceland Mantle Plume is south of the FFZ. We suggest moreover that interaction between the Iceland Mantle Plume and the Reykjanes Ridge is responsible for (1) the increase in spreading rates along this ridge at around $25 \mathrm{Ma}$ (Figure 8) and (2) resulting differential spreading between the Reykjanes, Kolbeinsey and Mohns Ridges and relative displacements along the FFZ and JMFZ during the Miocene (Figure 10). Both the stress due to development of the Icelandic Plateau [Doré et al., 2008] and the relative displacement along fracture zones, due to differential spreading, could explain the Miocene phase of deformation in the Vøring Basin and in the NE FaeroeShetland Basin, along preexisting inversion features, domes and anticlines that formed during the late Eocene to early Oligocene.

\section{Conclusions}

[43] 1. Our new kinematic model of Europe, relative to a stationary Greenland plate during the opening of the NE Atlantic, ensures a good fit of the magnetic anomalies for the complex Jan Mayen Segment, especially around the Aegir Ridge.

[44] 2. The model predicts differences in direction and rate of spreading among the Reykjanes, Jan Mayen and Mohns Segments. Rifting of the JMMC off Greenland generated counterclockwise rotation $\left(\sim 30^{\circ}\right)$ of the JMMC, fan-shaped spreading along the Aegir Ridge and clockwise rotation $\left(\sim 10^{\circ}\right)$ of the eastern side of the Aegir Ridge.

[45] 3. Differential seafloor spreading of the Reykjanes, Mohns and Aegir/Kolbeinsey Ridges generated relative displacements along the FFZ and JMFZ and relative rotation of each segment. Our model predicts a main period of leftlateral slip, of up to $45 \mathrm{~km}$ along the FFZ from the midEocene to late Oligocene (circa 47.1-26.6 Ma,) and up to $20 \mathrm{~km}$ along the JMFZ from the late Eocene to early Oligocene (circa 36.6-33.3 Ma) and during the Miocene (circa 26.4-10.3 Ma). These periods coincide with the development of compressional structures on the Faeroe-Rockall Plateau and Norwegian Margin, respectively.

[46] 4. We suggest that differential spreading was responsible for (1) left-lateral reactivation of NW-SE trending lineaments along the line of the JMFZ, in the late Eocene to early Oligocene and mostly during the Miocene, and resulting development of inversion structures on the Norwegian Margin; (2) constrictional strain, for which the principal directions of shortening trend approximately N-S and E-W, left-lateral strike-slip along NW trending transfer zones and reactivation of preexisting structures in the Eocene and early Oligocene, resulting in the development of inversion structures of various trends (NW-SE to NE-SW) on the FaeroeRockall Plateau; and (3) left-lateral reactivation of NW trending transfer zones, subparallel to the FFZ, that probably initiated the Fugløy Ridge in the NE Faeroe-Shetland Basin during the Eocene and Oligocene.

[47] 5. We suggest that the position of the Iceland Mantle Plume beneath the eastern Greenland margin, in the late

\begin{abstract}
Figure 11. Positions relative to stationary Greenland plate of Europe, Jan Mayen Microcontinent (JMMC) and Iceland Mantle Plume at intervals of $10 \mathrm{Myr}$, according to stationary hot spot model of Lawver and Müller [1994] and moving hot spot model of Mihalffy et al. [2008]. Timing is (a) late Paleocene, 55.9 Ma; (b) late Eocene, 36.6 Ma ; (c) early Miocene, $19.6 \mathrm{Ma}$; and (d) present. Relative positions of magnetic anomalies and continent-ocean boundaries (COB) in NE Atlantic are from our Model 2. Relative positions of European coastline and magnetic anomalies of oceanic domains other than the NE Atlantic are from Global EarthByte Gplates Model (rotation poles from Gaina et al. [2002]). Inversion structures are from Doré et al. [2008], Johnson et al. [2005] and Tuitt et al. [2010] and their relative positions are from Global EarthByte Model (rotation poles from Gaina et al. [2002]). Onshore and offshore Tertiary lavas are from Storey et al. [2007] and dike swarms from Upton [1988]. Ages of magmatic activity (Figure 11a) in west and east Greenland and in the British Isles are from White and McKenzie [1989]. Map projection is Universal Transverse Mercator (UTM, WGS 1984, zone 27N). Abbreviations (north to south): (1) fracture zones: GFZ, Greenland Fracture Zone; SFZ, Senja Fracture Zone; JMFZ, Jan Mayen Fracture Zone (west and east); FFZ, Faeroe Fracture Zone; CGFZ, Charlie Gibbs Fracture Zone; (2) inversion features: ND, Naglfar Dome; HD, Hedda Dome; VD, Vema Dome; HHA, Helland Hansen Arch; MA, Modgunn Arch; ID, Isak Dome; HSD, Havsule Dome; OL, Ormen Lange Dome; FR, Fugløy Ridge; MGR, Munkagrunnar Ridge; JA, Judd Anticline; FB, Faeroe Bank; BBB, Bill Bailey's Bank; WTR, Wyville Thomson Ridge; YR, Ymir Ridge; AD, Alpin Dome; LB, Lousy Bank; NHBFC, North Hatton Bank Fold Complex; LFC, Lyonesse Fold Complex; MHBFC, Mid-Hatton Bank Fold Complex.
\end{abstract}


Eocene and Oligocene, was responsible for the separation of the JMMC and subsequent differential spreading and deformation along the European Margin. During the Miocene, the Iceland Mantle Plume remained beneath the Reykjanes Ridge, and resulting volcanic activity formed the Iceland Plateau. Spreading rates were greater along the Reykjanes Ridge, triggering relative displacements along the FFZ and JMFZ during the Miocene. We therefore suggest that the Icelandic Mantle Plume was responsible for (1) differential seafloor spreading in the NE Atlantic and (2) postrift deformation on the Norwegian Margin and Faeroe-Rockall Plateau.

[48] Acknowledgments. We would like to thank Chevron USA for funding the $\mathrm{PhD}$ of E. Le Breton and in particular Peter Connolly for backing the project. We also thank Pierrick Roperch of the University of Rennes 1 for his help with the numerical restorations and two anonymous reviewers for their helpful comments.

\section{References}

Andersen, O. B., P. Knudsen, and P. A. M. Berry (2010), The DNSC08GRA global marine gravity field from double retracked satellite altimetry, J. Geod., 84(3), 191-199, doi:10.1007/s00190-009-0355-9.

Anell, I., H. Thybo, and I. M. Artemieva (2009), Cenozoic uplift and subsidence in the North Atlantic region: Geological evidence revisited, Tectonophysics, 474(1-2), 78-105, doi:10.1016/j. tecto 2009.04 .006 .

Arriagada, C. (2004), Rotations tectoniques et déformation de l'avant arc des Andes centrales au cours du Cénozoïque, in Mémoire de Géosciences Rennes, vol. 107, 308 pp., Univ. de Rennes, Rennes, France.

Arriagada, C., P. Roperch, C. Mpodozis, and P. R. Cobbold (2008), Paleogene building of the Bolivian Orocline: Tectonic restoration of the central Andes in 2-D map view, Tectonics, 27, TC6014, doi:10.1029/ 2008TC002269

Audibert, M. (1991), Déformation discontinue et rotations de blocs, $\mathrm{PhD}$ thesis, 250 pp., Univ. de Rennes 1, Rennes, France.

Bohnhoff, M. (2004), Crustal structure of the southeastern Iceland-Faeroe Ridge (IFR) from wide aperture seismic data, J. Geodyn., 37(2), 233-252, doi:10.1016/j.jog.2004.02.004

Boldreel, L. O., and M. S. Andersen (1993), Late Pliocene to Miocene compression in the Faeroe-Rockall area, in Petroleum Geology of Northwest Europe: Proceedings of the 4th Conference, edited by J. R. Parker, pp. 1025-1034, Geol. Soc., London.

Boldreel, L. O., and M. S. Andersen (1998), Tertiary compressional structures on the Faroe-Rockall Plateau in relation to northeast Atlantic ridge-push and Alpine foreland stresses, Tectonophysics, 300(1-4), 13-28, doi:10.1016/S0040-1951(98)00231-5.

Bott, M. H. P. (1985), Plate tectonic evolution of the Icelandic Transverse Ridge and adjacent regions, J. Geophys. Res., 90(B12), 9953-9960, doi:10.1029/JB090iB12p09953.

Bott, M. H. P. (1987), The continental margin of central east Greenland in relation to North Atlantic plate tectonic evolution, J. Geol. Soc., 144(4), 561-568, doi:10.1144/gsjgs.144.4.0561.

Bourgeois, O., P. R. Cobbold, D. Rouby, and J.-C. Thomas (1997), Least squares restoration of Tertiary thrust sheets in map view, Tajik depression, central Asia, J. Geophys. Res., 102(B12), 27,553-27,573, doi:10.1029/97JB02477.

Boyden, J. A., R. D. Müller, M. Gurnis, T. H. Torsvik, J. A. Clark, M. Turner, H. Ivey-Law, J. Watson, and J. S. Cannon (2011), Nextgeneration plate-tectonic reconstructions using GPlates, in Geoinformatics: Cyberinfrastructure for the Solid Earth Sciences, edited by G. R. Keller and C. Baru, pp. 95-114, Cambridge Univ. Press, Cambridge, U. K., doi:10.1017/CBO9780511976308.008

Brekke, H. (2000), The tectonic evolution of the Norwegian Sea Continental Margin with emphasis on the Voring and More Basins, in Dynamics of the Norwegian Margin, edited by A. Nottvedt, Geol. Soc. Spec. Publ., 167, 327-378, doi:10.1144/GSL.SP.2000.167.01.13.

Bullard, E., J. E. Everett, and G. Smith (1965), The fit of the continents around the Atlantic, Philos. Trans. R. Soc. A, 258(1088), 41-51, doi:10.1098/rsta.1965.0020

Cande, S. C., and D. V. Kent (1995), Revised calibration of the geomagnetic polarity timescale for the Late Cretaceous and Cenozoic, J. Geophys. Res. 100, 6093-6095, doi:10.1029/94JB03098.

Chang, T. (1987), On the statistical properties of estimated rotations, J. Geophys. Res., 92, 6319-6329, doi:10.1029/JB092iB07p06319.
Cobbold, P. R. (1979), Removal of finite deformation using strain trajectories, J. Struct. Geol., l(1), 67-72, doi:10.1016/0191-8141(79)90022-1.

Davies, R., I. Cloke, J. Cartwright, A. Robinson, and C. Ferrero (2004), Post-breakup compression of a passive margin and its impact on hydrocarbon prospectivity: An example from the Tertiary of the Faeroe-Shetland Basin, United Kingdom, AAPG Bull., 88(1), 1-20, doi:10.1306/ 09030303008 .

Doré, A. G., and E. R. Lundin (1996), Cenozoic compressional structures on the NE Atlantic margin: Nature, origin and potential significance for hydrocarbon exploration, Petrol. Geol., 2, 299-311, doi:10.1144/ petgeo.2.4.299.

Doré, A. G., E. R. Lundin, N. J. Kusznir, and C. Pascal (2008), Potential mechanisms for the genesis of Cenozoic domal structures on the $\mathrm{NE}$ Atlantic margin: Pros, cons and some new ideas, in The Nature and Origin of Compression in Passive Margins, edited by H. Johnson et al., Geol. Soc. Spec. Publ., 306, 1-26, doi:10.1144/SP306.1.

Forsyth, D., and S. Uyeda (1975), On the relative importance of the driving forces of plate motion, Geophys. J. R. Astron. Soc., 43, 163-200, doi:10.1111/j.1365-246X.1975.tb00631.x.

Gaina, C., W. Roest, and R. Müller (2002), Late Cretaceous-Cenozoic deformation of northeast Asia, Earth Planet. Sci. Lett., 197(3-4), 273-286, doi:10.1016/S0012-821X(02)00499-5.

Gaina, C., L. Gernigon, and P. Ball (2009), Palaeocene-Recent plate boundaries in the NE Atlantic and the formation of the Jan Mayen microcontinent, J. Geol. Soc., 166, 601-616, doi:10.1144/0016-76492008-112. Geoffroy, L. (2005), Volcanic passive margins, C. R. Geosci., 337(16), 1395-1408, doi:10.1016/j.crte.2005.10.006

Gernigon, L., O. Olesen, J. Ebbing, S. Wienecke, C. Gaina, J. O. Mogaard, M. Sand, and R. Myklebust (2009), Geophysical insights and early spreading history in the vicinity of the Jan Mayen Fracture Zone, NorwegianGreenland Sea, Tectonophysics, 468(1-4), 185-205, doi:10.1016/j.tecto. 2008.04.025.

Hamann, N. E., R. C. Whittaker, and L. Stemmerik (2005), Geological development of the Northeast Greenland Shelf, in Petroleum Geology: North-West Europe and Global Perspectives: Proceedings of the 6th Petroleum Geology Conference, Pet. Geol. Conf. Ser., vol. 6, edited by A. G. Doré and B. A. Vining, pp. 887-902, Geol. Soc., London.

Hellinger, S. J. (1981), The uncertainties of finite rotations in plate tectonics, J. Geophys. Res., 86, 9312-9318, doi:10.1029/JB086iB10p09312.

Hendriks, B., P. Andriessen, Y. Huigen, C. Leighton, T. Redfield, G. Murrell, K. Gallagher, and S. B. Nielsen (2007), A fission track data compilation for Fennoscandia, Norw. J. Geol., 87, 143-155.

Hitchen, K. (2004), The geology of the UK Hatton-Rockall margin, Mar. Pet. Geol., 21, 993-1012, doi:10.1016/j.marpetgeo.2004.05.004.

Holford, S. P., P. F. Green, I. R. Duddy, J. P. Turner, R. R. Hillis, and M. S. Stoker (2009), Regional intraplate exhumation episodes related to plate-boundary deformation, Geol. Soc. Am. Bull., 121(11-12), 1611-1628, doi:10.1130/B26481.1.

Japsen, P., P. F. Green, J. M. Bonow, E. S. Rasmussen, and J. A. Chalmers (2010), Episodic uplift and exhumation along North Atlantic passive margins: Implications for hydrocarbon prospectivity, in Petroleum Geology: From Mature Basins to New Frontiers: Proceedings of the 7th Petroleum Geology Conference, edited by B. A. Vinning and S. C. Pickering, pp. 979-1004, Geol. Soc., London.

Johnson, H., J. D. Ritchie, K. Hitchen, D. B. Mcinroy, and G. S. Kimbell (2005), Aspects of the Cenozoic deformational history of the northeast Faroe-Shetland Basin, Wyville-Thomson Ridge and Hatton Bank areas, in Petroleum Geology: North-West Europe and Global Perspectives: Proceedings of the 6th Petroleum Geology Conference, edited by A. G. Doré and B. A. Vining, pp. 993-1007, Geol. Soc., London.

Jones, S. M., N. White, and J. Maclenna (2002), V-shaped ridges around Iceland: Implications for spatial and temporal patterns of mantle convection, Geochem. Geophys. Geosyst. 3(10), 1059, doi:10.1029/2002GC000361.

Jurdy, D. M., and M. Stefanick (1987), Errors in plate rotations as described by covariance matrices and their combination in reconstructions, J. Geophys. Res., 92, 6310-6318, doi:10.1029/JB092iB07p06310.

Kimbell, G. S., J. D. Ritchie, H. Johnson, and R. W. Gatliff (2005), Controls on the structure and evolution of the NE Atlantic margin revealed by regional potential field imaging and 3D modelling, in Petroleum Geology: North-West Europe and Global Perspectives: Proceedings of the 6th Petroleum Geology Conference, edited by A. G. Doré and B. A. Vining, pp. 933-945, Geol. Soc., London.

Kirkwood, B. H., J.-Y. Royer, T. C. Chang, and R. G. Gordon (1999), Statistical tools for estimating and combining finite rotations and their uncertainties, Geophys. J. Int., 137(2), 408-428, doi:10.1046/j.1365246X.1999.00787.X.

Kodaira, S., R. Mjelde, K. Gunnarsson, H. Shiobara, and H. Shimamura (1998), Structure of the Jan Mayen microcontinent and implications for 
its evolution, Geophys. J. Int., 132, 383-400, doi:10.1046/j.1365246x.1998.00444.x.

Lawver, L. A., and R. D. Müller (1994), Iceland hotspot track, Geology, 22 , 311-314, doi:10.1130/0091-7613(1994)022<0311:IHT>2.3.CO;2.

Le Breton, E. (2012), Differential spreading along the NE Atlantic ridge system and post-breakup deformation of the adjacent continental margins, thèse doctorat, 316 pp., Univ. Rennes 1, Rennes, France.

Løseth, H., and S. Henriksen (2005), A middle to late Miocene compression phase along the Norwegian passive margin, in Petroleum Geology: North-West Europe and Global Perspectives: Proceedings of the 6th Petroleum Geology Conference, edited by A. G. Doré and B. A. Vining, pp. 845-859, Geol. Soc., London.

Lundin, E. R., and A. G. Doré (2002), Mid-Cenozoic post-breakup deformation in the "passive" margins bordering the Norwegian-Greenland Sea, Mar. Pet. Geol., 19, 79-93, doi:10.1016/S0264-8172(01)00046-0.

Macnab, R., J. Verhoef, W. Roest, and J. Arkani-Hamed (1995), New database documents the magnetic character of the Arctic and North Atlantic, Eos Trans. AGU, 76(45), 449, doi:10.1029/95EO00278.

Maus, S., et al. (2009), EMAG2: A 2-arc min resolution Earth Magnetic Anomaly Grid compiled from satellite, airborne, and marine magnetic measurements, Geochem. Geophys. Geosyst., 10, Q08005, doi:10.1029/ 2009GC002471.

McKenzie, D. (1978), Some remarks on the development of sedimentary basins, Earth Planet. Sci. Lett., 40, 25-32, doi:10.1016/0012-821X(78) 90071-7.

Mihalffy, P., B. Steinberger, and H. Schmeling (2008), The effect of the large-scale mantle flow field on the Iceland hotspot track, Tectonophysics, 447(1-4), 5-18, doi:10.1016/j.tecto.2006.12.012.

Mitchell, A. H., and H. G. Reading (1969), Continental margins, geosynclines, and ocean floor spreading, J. Geol., 77(6), 629-646, doi:10.1086/ 627462 .

Mjelde, R., T. Raum, J. Breivik, and J. I. Faleide (2008), Crustal transect across the North Atlantic, Mar. Geophys. Res., 29(2), 73-87, doi:10.1007/s11001-008-9046-9.

Mosar, J., G. Lewis, and T. Torsvik (2002), North Atlantic sea-floor spreading rates: Implications for the Tertiary development of inversion structures of the Norwegian-Greenland Sea, J. Geol. Soc., 159, 503-515, doi:10.1144/0016-764901-135.

Müller, R. D., J.-Y. Royer, S. C. Cande, W. R. Roest, and S. Maschenkov (1999), New constraints on the Late Cretaceous/Tertiary plate tectonic evolution of the Caribbean, in Sedimentary Basins of the World, vol. 4 Caribbean Basins, edited by P. Mann, pp. 33-59, Elsevier Sci., Amsterdam, doi:10.1016/S1874-5997(99)80036-7.

Müller, R. D., C. Gaina, W. R. Roest, and D. L. Hansen (2001), A recipe for microcontinent formation, Geology, 29(3), 203-206, doi:10.1130/00917613(2001)029<0203:ARFMF>2.0.CO;2.

Nunns, A. G. (1983), Plate tectonic evolution of the Greenland-Scotland Ridge and surrounding regions, in Structure and Development of the Greenland-Scotland Ridge: New Methods and Concepts, edited by M. H. P. Bott et al., pp. 11-30, Plenum, New York.

Olesen, O., J. Ebbing, E. Lundin, E. Mauring, J. R. Skilbrei, and T. H. Torsvik (2007), An improved tectonic model for the Eocene opening of the Norwegian-Greenland Sea: Use of modern magnetic data, Mar. Pet. Geol., 24, 53-66, doi:10.1016/j.marpetgeo.2006.10.008.

Pitman, W. C., and M. Talwani (1972), Sea-floor spreading in the North Atlantic, Geol. Soc. Am. Bull., 83(3), 619-646, doi:10.1130/00167606(1972)83[619:SSITNA]2.0.CO;2.

Price, S., J. Brodie, A. Whitiam, and R. A. Y. Kent, (1997), Mid-Tertiary rifting and magmatism in the Traill $\varnothing$ region, east Greenland, J. Geol. Soc., 154, 419-434, doi:10.1144/gsjgs.154.3.0419.

Ritchie, J. D., H. Johnson, and G. S. Kimbell (2003), The nature and age of Cenozoic contractional deformation within the NE Faroe-Shetland Basin, Mar. Pet. Geol., 20(5), 399-409, doi:10.1016/S0264-8172(03)00075-8.

Ritchie, J. D., H. Johnson, M. F. Quinn, and R. W. Gatliff (2008), The effects of Cenozoic compression within the Faroe-Shetland Basin and adjacent areas, in The Nature and Origin of Compression in Passive Margins, edited by H. Johnson et al., Geol. Soc. Spec. Publ., 106, 121-136, doi:10.1144/SP306.5.
Rouby, D., P. R. Cobbold, P. Szatmari, S. Demercian, D. Coelho, and J. A. Rici (1993), Least-squares palinspastic restoration of regions of normal faulting: Application to the Campos Basin (Brazil), Tectonophysics, 221(3-4), 439-452, doi:10.1016/0040-1951(93)90172-G

Saunders, A. D., J. G. Fitton, A. C. Kerr, M. J. Norry, and R. W. Kent (1997), The North Atlantic Igneous Province, in Large Igneous Provinces Continental, Oceanic, and Planetary Flood Volcanism, Geophys. Monogr. Ser., vol. 100, edited by J. J. Mahoney and M. F. Coffin, pp. 45-93, AGU, Washington, D. C., doi:10.1029/GM100p0045.

Scott, R. A., L. A. Ramsey, S. M. Jones, S. Sinclair, and C. S. Pickles (2005), Development of the Jan Mayen microcontinent by linked propagation and retreat of spreading ridges, in Onshore-Offshore Relationships on the North Atlantic Margin, edited by B. T. G. Wandas et al., Norw. Pet. Soc. Spec. Publ., 12, 69-82, doi:10.1016/S0928-8937(05)80044-X. Skogseid, J., S. Planke, J. I. Faleide, T. Pedersen, O. Eldholm, and F. Neverdal (2000), NE Atlantic rifting and volcanic margin formation, in Dynamics of the Norwegian Margin, edited by A. Nottvedt et al., Geol. Soc. Spec. Publ., 167, 295-326, doi:10.1144/GSL.SP.2000.167.01.12.

Smallwood, J. R. (2004), Tertiary inversion in the Faroe-Shetland Channel and the development of major erosional scarps, Geol. Soc. Mem., 29(1), 187-198, doi:10.1144/GSL.MEM.2004.029.01.18.

Srivastava, S. P., and W. R. Roest (1999), Extent of oceanic crust in the Labrador Sea, Mar. Pet. Geol., 16(1), 65-84, doi:10.1016/ S0264-8172(98)00041-5.

Srivastava, S. P., and C. R. Tapscott (1986), Plate kinematics of the North Atlantic, in The Geology of North America, vol. N, The Western North Atlantic Region, edited by P. R. Vogt and B. E. Tucholke, pp. 379-404, Geol. Soc. of Am., Boulder, Colo.

Stock, J., P. Molnar, and T. Chang (1990), The rotation group in plate tectonics and the representation of uncertainties of plate reconstructions, Geophys. J. Int., 101, 649-661, doi:10.1111/j.1365-246X.1990.tb05576.x.

Stoker, M. S., R. J. Hoult, T. Nielsen, B. O. Hjelstuen, J. S. Laberg, and P. M. Shannon (2005), Sedimentary and oceanographic responses to early Neogene compression on the NW European margin, Mar. Pet. Geol., 22, 1031-1044, doi:10.1016/j.marpetgeo.2005.01.009.

Storey, M., R. A. Duncan, and C. Tegner (2007), Timing and duration of volcanism in the North Atlantic Igneous Province: Implications for geodynamics and links to the Iceland hotspot, Chem. Geol., 241(3-4), 264-281, doi:10.1016/j.chemgeo.2007.01.016

Stuevold, L. M., J. Skogseid, and O. Eldholm (1992), Post-Cretaceous uplift events on the Voring continental margin, Geology, 20, 919-922, doi:10.1130/0091-7613(1992)020<0919:PCUEOT>2.3.CO;2.

Talwani, M., and O. Eldholm (1977), Evolution of the NorwegianGreenland Sea, Geol. Soc. Am. Bull., 88(7), 969-999, doi:10.1130/ 0016-7606(1977)88<969:EOTNS > 2.0.CO;2.

Torsvik, T. H., R. Van der Voo, J. G. Meert, J. Mosar, and H. J. Walderhaug (2001), Reconstructions of the continents around the North Atlantic at about the 60th parallel, Earth Planet. Sci. Lett., 187(1-2), 55-69, doi:10.1016/S0012-821X(01)00284-9.

Tuitt, A., J. R. Underhill, J. D. Ritchie, H. Johnson, and K. Hitchen (2010), Timing, controls and consequences of compression in the Rockall-Faroe area of the NE Atlantic Margin, in Petroleum Geology: From Mature Basins to New Frontiers Proceedings of the 7th Petroleum Geology Conference, edited by B. A. Vining and S. C. Pickering, pp. 963-977, Geol. Soc., London.

Unternehr, P. (1982), Etude structurale et cinématique de la mer de Norvège et du Groenland. Evolution du microcontinent de Jan Mayen, PhD thesis, 228 pp., Univ. de Bretagne Occidentale, Brest, France.

Upton, B. G. J. (1988), History of Tertiary igneous activity in the N Atlantic borderlands, in Early Tertiary Volcanism and the Opening of the NE Atlantic, edited by A. C. Morton and L. M. Parson, Geol. Soc. Spec. Publ., 39, 429-453, doi:10.1144/GSL.SP.1988.039.01.38.

Vogt, P. R., and O. E. Avery (1974), Detailed magnetic surveys in the northeast Atlantic and Labrador Sea, J. Geophys. Res., 79, 363-389, doi:10.1029/JB079i002p00363.

White, R., and D. McKenzie (1989), Magmatism at rift zones: The generation of volcanic continental margins and flood basalts, J. Geophys. Res., 94, 7685-7729, doi:10.1029/JB094iB06p07685. 